THE TIMELINESS OF ACCOUNTING WRITE-DOWNS BY U.S.

FINANCIAL INSTITUTIONS DURING THE FINANCIAL CRISIS OF

2007-2008

by

Dushyantkumar Vyas

A thesis submitted in conformity with the requirements

for the degree of Doctor of Philosophy

Joseph L. Rotman School of Management

University of Toronto

July, 2010

(C) Copyright by Dushyantkumar Vyas (2010) 


\title{
THE TIMELINESS OF ACCOUNTING WRITE-DOWNS BY U.S. FINANCIAL INSTITUTIONS DURING THE FINANCIAL CRISIS OF 2007-2008
}

by Dushyantkumar Vyas (2010)

A thesis submitted in conformity with the requirements for the degree of Doctor of Philosophy, Joseph L. Rotman School of Management, University of Toronto.

\begin{abstract}
This study examines the timeliness of write-downs taken by U.S. financial institutions during the financial crisis of 2007-2008. The timeliness of write-downs is measured by benchmarking the quarterly accounting write-down schedule with the devaluation schedule implied by credit indices such as the ABX. The results show that accounting write-downs are less timely than the devaluations implied by credit indices. In a cross-sectional analysis of the determinants of the timeliness of write-downs, I document that higher corporate governance quality is positively related to timelier write-downs. Furthermore, I observe that regulatory investigations and litigation pressure are positively related to the timeliness of write-downs, whereas the writedowns by firms with more complex exposures, higher financial leverage, and tighter regulatory constraints are less timely. In addition, I control for numerous exposure-specific characteristics and document that less risky exposures, and exposures that were affected later during the financial crisis, were written down later. Regarding the consequences of timeliness, this study finds that the exposure to risky assets is reflected faster in stock returns for firms with timelier write-downs.
\end{abstract}




\section{ACKNOWLEDGEMENTS}

I thank my supervisors, Jeffrey Callen and Gordon Richardson, for patiently guiding me through my doctoral studies; my dissertation committee members Franco Wong and Alan White; and James Wahlen (the external reviewer) for offering helpful comments on and constructive criticism of my thesis. I am also greatly indebted to Gus De Franco and Ole-Kristian Hope for their counsel and support during the $\mathrm{PhD}$ and on the job market. I am also very thankful to Florin Vasvari and Regina Wittenberg-Moerman for their help and support throughout.

I owe special gratitude to my friends and colleagues in the PhD program. They made life during the $\mathrm{PhD}$ much more enjoyable. These include Gauri Bhat, Alastair Lawrence, Stephannie Larocque, Hamed Mahmudi, Miguel Minutti, and Mike Pavlin. Thank you also to Grace Raposo at the $\mathrm{PhD}$ office for her great help and support throughout the $\mathrm{PhD}$ program.

Finally, I deeply appreciate the love, support, and encouragement of my family including, in particular, my wife, Vidisha. I am also profoundly grateful to my parents and my sister for their love and encouragement throughout. I dedicate this dissertation to my wonderful son, Keshav, who is always such a great joy to be with. 


\section{TABLE OF CONTENTS}

ABSTRACT II

ACKNOWLEDGEMENTS III

TABLE OF CONTENTS IV IV

LIST OF TABLES VI

CHAPTER 1 INTRODUCTION

CHAPTER 2 LITERATURE REVIEW AND HYPOTHESES DEVELOPMENT 6

2.1. LACK OF TIMELINESS IN WRITE-DOWNS TAKEN BY FINANCIAL INSTITUTIONS 6

2.1.1. BACKGROUND 6

2.1.2. PREDICTIONS BASED ON AGENCY THEORY 7

2.2. CONSEQUENCES OF LACK OF TIMELINESS 9

CHAPTER 3 DATA AND SAMPLE 12

CHAPTER 4 MEASUREMENT OF KEY VARIABLES 16

4.1. TIMELINESS OF WRITE-DOWNS 16

4.2. INCENTIVES AND CORPORATE GOVERNANCE 21

CHAPTER 5 EMPIRICAL TESTS 23

5.1. LACK OF TIMELINESS IN WRITE-DOWNS 24

5.2. CROSS-SECTIONAL DETERMINANTS OF THE TIMELINESS OF WRITE-DOWNS 24

5.3. TIMELINESS OF STOCK MARKET ADJUSTMENTS 28

5.4. ADDITIONAL ANALYSES 31

5.4.1. EX ANTE MEASURE OF TRANSPARENCY CONSTRUCTED USING THE 2006 ANNUAL REPORT DISCLOSURES

5.4.2. ALTERNATIVE MARKET-BASED MEASURE OF EXPOSURE TO RISKY ASSETS 33 
5.4.3. ADDITIONAL CONTROLS FOR EXPOSURE-SPECIFICITY 34

5.4.4. ADDITIONAL CONTROLS FOR ACCOUNTING TREATMENT 37

5.4.5. ADDITIONAL CONTROL FOR EX ANTE DISCLOSURE QUALITY IN TESTS OF H2

(TIMELINESS OF STOCK MARKET REFLECTION OF EXPOSURE TO RISKY ASSETS) 39

5.4.6. ALTERNATE EXPLANATIONS 39

CHAPTER 6 CONCLUSIONS 42

REFERENCES 44

APPENDIX 1: MAPPING BETWEEN TYPES OF WRITE-DOWNS AND CREDIT INDEX BENCHMARKS 49

APPENDIX 2: ITEMS COMPRISING THE ISS CORPORATE GOVERNANCE QUOTIENT $\operatorname{INDEX}(C G Q) \quad 50$

APPENDIX 3: EXCESS CEO COMPENSATION AND EXPOSURE TO RISKY ASSETS 51

APPENDIX 4: DISCLOSURE INDEX BASED ON THE SSG BEST PRACTICES

RECOMMENDATIONS 54

APPENDIX 5: ALTERNATIVE DEPENDENT VARIABLE 55

APPENDIX 6: A BRIEF REVIEW OF FINANCIAL REPORTING ISSUES DURING THE CRISIS 


\section{LIST OF TABLES}

DATA AND SAMPLE: DATA SOURCES, VARIABLE DEFINITIONS AND SAMPLE CONSTITUTION 60

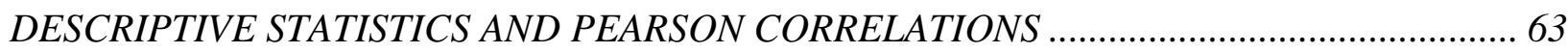

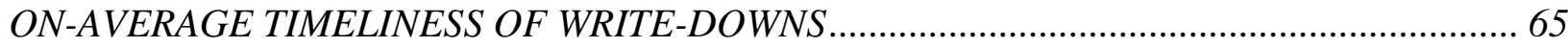

CROSS-SECTIONAL DETERMINANTS OF THE TIMELINESS OF WRITE-DOWNS ............ 66

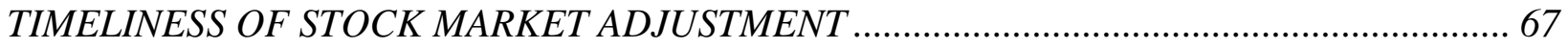

TIMELINESS OF STOCK MARKET ADJUSTMENT: 2006 ANNUAL REPORT DISCLOSURES AS AN EX ANTE TRANSPARENCY MEASURE .......................................................... 69

TIMELINESS OF STOCK MARKET ADJUSTMENT: USING A MARKET-BASED MEASURE OF EXPOSURE TO RISKY ASSETS .............................................................................. 70 CROSS SECTIONAL DETERMINANTS OF TIMELINES OF WRITE-DOWNS: ADDITIONAL

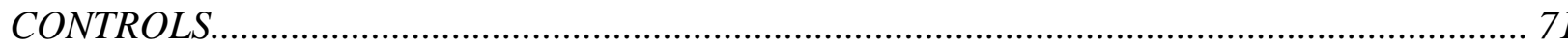




\section{Chapter 1 Introduction}

The subprime crisis that began in early 2007 evolved into a full-blown financial crisis by the end of 2008. Problems in the U.S. subprime mortgage loans sector developed into a widespread credit crunch that spanned various asset markets throughout the world - making this the worst economic crisis since the Great Depression of the 1930s. Prior to the crisis, financial institutions took on large exposures to subprime mortgage-backed assets and other complex structured finance instruments, and undertook billions of dollars worth of write-downs as the risks unraveled during 2007 and 2008.

Given the extent and complexity of these exposures, transparent financial reporting can help the various stakeholders of financial institutions understand the risks associated with these exposures. Transparent financial reporting involves timely asset write-downs as the losses become apparent to institutions. However, if for the time period studied, the incentives of managers and shareholders are not aligned, or corporate governance quality is inadequate (as argued by Bicksler 2008, Borio 2008, Strebel 2008, Hull 2009, and Kirkpatrick 2009), then one would expect, given agency theory, to observe an opportunistic lack of timeliness in the writedowns taken by financial institutions. Managers who took on exposure to risky instruments would be motivated to conceal these risks to avoid potential labor and capital market penalties, despite the demand for transparency by shareholders. Indeed, as the crisis evolved, a plethora of shareholder lawsuits were filed against financial institutions alleging that, inter alia, the writedowns of subprime and structured finance exposures were not timely enough (Dickey, King, and Shih 2008). ${ }^{1}$

\footnotetext{
${ }^{1}$ Throughout this study, "write-downs" refer to net credit losses recognized by financial institutions during the crisis. These credit losses were recognized through a variety of accounting treatments, including fair value adjustments, impairment charges, realized losses on settlement of positions, and credit loss provisioning.
} 
In this study, the timeliness of write-downs is measured as the difference between the cumulative quarterly accounting write-downs taken by the financial institutions in the sample and the write-downs implied by exposure-specific credit indices. One of the features of the financial crisis was that it evolved in waves, with certain exposures being affected later than the others (Ryan 2008). For example, subprime exposures were affected earlier, followed by Alternative-A (or "Alt-A"), commercial mortgage, and prime mortgage exposures. To ensure that the measurement of timeliness is not merely a reflection of the nature of the underlying exposures, it is important to ensure that the benchmark indices are specific to the exposures being written down. The measurement approach followed in this study confronts this problem by mapping the write-downs pertaining to different types of exposures to the appropriate exposurespecific credit indices (such as the ABX, CMBX and LCDX indices constructed by Markit Partners). ${ }^{2}$

I find that the quarterly accounting write-downs lagged the write-down schedule implied by the credit indices. This result suggests inadequate financial reporting transparency by financial institutions during the crisis. Among other things, this lack of timeliness could be a manifestation of ineffective corporate governance. I explore this argument further by examining the cross-sectional determinants of the timeliness of write-downs. Consistent with my predictions, I find that corporate governance quality is positively related to the timeliness of write-downs. Further, I document that firms with exposure to regulatory investigations and credit-crisis-related litigation take more timely write-downs, while firms with greater financial leverage, tighter regulatory constraints, and more complex exposures are less timely in their write-downs. These results highlight the role of internal and external oversight mechanisms,

\footnotetext{
${ }^{2}$ Market participants such as Citigroup, UBS, and Morgan Stanley have cited the use of indices such as the ABX as an input for their write-downs. See "A subprime gauge in many ways?” The Wall Street Journal, Dec 12, 2007.
} 
financing constraints, and litigation pressure in influencing the loss recognition policies of financial institutions during the crisis.

I also control for a number of exposure-specific characteristics such as credit ratings, tranche structure, geographical distribution, and monoline guarantees. I find that less risky / more senior exposures, and exposures that were affected later on during the financial crisis were written down later. The main cross-sectional results of this study are robust to controlling for these potentially important characteristics.

Further, I consider two potentially important alternate explanations for the lack of timeliness of write-downs - valuation uncertainty, and signaling. The finding that more complex exposures were written down later is consistent with the valuation uncertainty explanation. This result supports the arguments that firms waited for some of the valuation uncertainty surrounding these complex positions to resolve before writing them down. However, the finding that less risky exposures were written down later is inconsistent with the signaling prediction. Other inferences, such as the role of corporate governance and litigation pressure, are robust to controlling for these alternate explanations. In summary, the results concerning the timeliness of write-downs point towards a complex interplay of multiple economic forces that affected accounting loss recognition during the crisis.

My primary capital market result is that the differences between the cumulative quarterly accounting write-downs and the write-downs implied by the credit indices are informative in explaining the cumulative quarterly stock returns during 2007 and 2008. Specifically, I find that the stock market reflects risk exposure faster for firms with timelier write-downs (i.e., for firms with write-down schedules that are closer to the schedule implied by the credit indices). 
Such a result is far from tautological: critics of those who would use credit indices such as the ABX as a "Level 2" market observable to guide what would otherwise be "Level 3" fair value write-downs claim that: a) these indices are an unreliable guide to fair value write-downs due to a lack of liquidity in the trading of these indices, and b) these indices are not representative of the exact exposures faced by a particular financial institution (Fender and Scheicher 2008, Stanton and Wallace 2009). ${ }^{3}$ These claims imply an inability to reject the null of my hypothesis: if the credit indices are unreliable, then the differences between the cumulative quarterly accounting write-downs and the index-implied write-downs should be un-informative in explaining the temporal and cross-sectional pattern of firm stock returns over the eight quarters of 2007 and 2008 examined in this study.

My rejection of the null in favor of the usefulness of my measure for the timeliness of write-downs lends support to the argument that credit indices such as the ABX provide a useful check for firms to benchmark their losses on risky exposures during the crisis. This finding is consistent with the claim made by the American Institute of Certified Public Accountants' Centre for Audit Quality (2007) that indices such as the ABX are useful as "Level 2" inputs for firms that are fair-valuing illiquid subprime mortgage-backed assets and other structured finance instruments.

In additional analyses, I examine the footnotes and MD\&A disclosures from fiscal 2006 annual reports. Using a disclosure index, I show that for firms that are ex ante more transparent about their exposure to risky assets, the stock market reflects risk exposure on a timelier basis. In other words, financial institutions that provide timelier information about their risk positions enable their investors to "mark down" these positions on a timelier basis. This research suggests that financial institutions that provide investors with better information about their risk positions

\footnotetext{
${ }^{3}$ See also, "Valuing securities: Don't mark to Markit." The Economist, March 6, 2008.
} 
and losses may be able to prevent managers ex ante from taking excessive exposure to risky positions that are not in the shareholder interest (e.g., Laux and Leuz 2009b).

The next chapter develops my hypotheses and reviews supporting literature. Chapter 3 describes the data and sample. Chapter 4 explains the measurement of the key variables. Chapter 5 discusses the empirical tests and results. Chapter 6 concludes. A brief review of the accounting issues pertaining to the crisis (especially fair value accounting) is provided in Appendix 6 . 


\section{Chapter 2 Literature Review and Hypotheses Development}

\subsection{Lack of Timeliness in Write-downs taken by Financial Institutions}

\subsubsection{Background}

A key feature of the current crisis is that financial institutions amassed large exposures to risky subprime and structured finance instruments, and took large accounting write-downs when the losses on these exposures became apparent during 2007 and 2008. Accounting standards such as the Statement of Financial Accounting Standards (SFAS) 157 emphasize the use of marketbased measures in arriving at fair value estimates of financial instruments. During the crisis, however, the markets for structured finance securities dried up. It became difficult for firms to observe direct market quotes ("Level 1" estimates) for these securities. As a result, financial institutions, to varying degrees, had to rely upon other market observables ("Level 2" estimates), including credit indices such as the $\mathrm{ABX}$. As the crisis progressed, these indices crashed leading many to argue that the prices of these indices reflected market fear and panic rather than "real" credit losses, and that fair value accounting that relied on these market observables was producing asset valuation estimates that were substantially lower than the "true" fundamental values (see Laux and Leuz 2009a, 2009b for a detailed account of this debate; see also Appendix 6 which provides a brief review of the fair value accounting issues pertaining to the crisis).

Concurrently, a number of shareholder lawsuits were launched against institutions affected by the crisis. Among other things, these lawsuits alleged that the accounting writedowns taken by financial institutions were insufficiently timely compared with the devaluations implied by credit indices such as the $\mathrm{ABX}$. For example, in a summary article on subprime litigation trends, Dickey, King, and Shih (2008) argue that:

"In most of the cases filed to date, in one form or another, plaintiffs' counsel challenges the integrity of the issuer's financial statements. At its core, the 
accounting issue is whether the issuer used appropriate methodologies to establish the "fair value" of the securities or instruments under the relevant provisions of GAAP, and whether it failed to take impairment charges or other write-downs on a timely basis."

\subsubsection{Predictions based on Agency Theory}

I empirically examine the timeliness of write-downs (or lack thereof) during the crisis by appealing to agency theory, which predicts that managers might not always act in the best interests of shareholders, and that they can make sub-optimal or self-maximizing decisions (Jensen and Meckling 1976). In a world where the interests of managers and shareholders are perfectly aligned and corporate governance is effective, there should be no reason to expect a delay in informing the shareholders about exposure to risky assets. In such a perfect scenario, managers would not have an incentive to conceal the losses when they become apparent, and would undertake timely asset write-downs. However, if the incentive structures prevalent in financial institutions create a wedge between the interests of managers and shareholders, and corporate governance quality is inadequate, then one would expect to observe opportunism in the timeliness with which impaired or non-performing assets are written down by financial institutions.

In a particularly prescient article, Rajan (2006) argues that the incentive structures of investment and bank managers in the period leading up to the crisis induced them to take on risk - particularly risk that was concealed from investors. Consistent with Rajan's assertion, financial institutions took on large exposures to risky, highly complex, and opaque financial instruments. ${ }^{4}$ More generally, the literature in financial accounting documents that agency costs affect the financial reporting practices of managers. For example, Healy (1985) documents that executives manage earnings to maximize bonus payments. Recent studies on segment disclosures

\footnotetext{
${ }^{4}$ In Appendix 3, I provide some corroborative evidence on the existence of incentive-related problems during the crisis by demonstrating that excess CEO compensation is positively related to the extent of exposure to risky assets.
} 
document that managers face agency costs of disclosure and opportunistically conceal negative segment information (Berger and Hann 2007, Hope and Thomas 2008). As Berger and Hann (2007) argue, if greater transparency reveals information about the extent of value-destruction at a firm, managers might have an incentive to conceal that information. In another context, Ali, Chen, and Radhakrishnan (2007) argue that family firms face lower compensation-related agency costs, and as a result, have better financial reporting quality. Relevant to my study, Ali et al. present evidence that firms with lower agency costs (family firms in their context) are more likely to warn investors about bad news.

This incentive for concealment can be curtailed by effective corporate governance. In the wake of the Enron accounting scandal, regulators and policy makers have been wary of corporate financial reporting practices and have advocated stronger corporate governance mechanisms to increase financial reporting quality. For example, the Sarbanes-Oxley Act is intended, at least in part, to enhance the role of corporate governance in improving the quality of financial reporting (Hutton 2007). Similarly, international accounting and finance research has documented that better corporate governance is related to higher quality disclosure and greater transparency (Ball, Robin and Wu 2003, Bushman, Piotroski and Smith 2004, Khanna, Palepu and Srinivasan 2004). At the firm-level, Ajinkya, Bhojraj and Sengupta (2005) find that better governed firms (with more outside directors and director ownership) are more likely to issue management forecasts. Further, firms with better governance issue more frequent and more accurate forecasts. Similarly, Karamanou and Vafaes (2005) find that firms with more effective board and audit committee structures are more likely to make or update earnings forecasts, and issue more accurate forecasts. In the context of the current crisis, however, it has been argued that corporate governance mechanisms in financial institutions were ineffective (Strebel 2008, Bicksler 2008). 
The discussion above indicates that inadequate corporate governance in financial institutions during the crisis could be related to the timeliness with which the institutions took their write-downs. I predict that firms with better corporate governance quality will be timelier in their write-downs. As stated earlier, I measure the timeliness of write-downs by benchmarking the quarterly accounting write-down schedule with the devaluation schedule implied by credit indices such as the $\mathrm{ABX}$. Based on the above discussion, my first set of hypotheses (in alternate form) is as follows:

H1(a): The quarterly accounting write-downs by financial institutions were less timely than the devaluations implied by the credit indices.

H1(b): Ceteris paribus, corporate governance quality is positively related to the timeliness of write-downs.

\subsection{Consequences of Lack of Timeliness}

While the academic accounting and finance literatures have long focused on the relation between financial reporting transparency and the cost of capital, this crisis points us more specifically towards the role of financial reporting in revealing value-relevant cash flow information concerning potential asset impairment. Thus, the relevant construct for my study is the timeliness with which the capital markets are able to adjust for potential impairment losses. A number of academic studies in finance and accounting examine the timeliness of stock-price adjustments to information in different settings. ${ }^{5}$ I focus on the role of timely write-downs in informing capital markets about a firm's risk positions, and thereby enabling timelier price adjustments to the firm's exposure to risky assets.

\footnotetext{
${ }^{5}$ See for example, Ball and Brown (1968), Fama, Fischer, Jensen and Roll (1969), Alford, Jones, Leftwich and Zmijewski (1993), Kasznik and Lev (1995), Hou and Moskowitz (2005), Butler, Kraft and Weiss (2007), Bushman, Smith and Wittenberg-Moerman (2008), and Callen, Khan and Lu (2009).
} 
Given concerns about asset quality, the crisis has led to a general decline in the stock prices of many financial institutions. To the extent that the stock price decline during the crisis is due to poor asset quality, it should be related to a shift in the market's expectations about exposure to risky assets. The timelier the write-downs, the more informed the capital markets would be about risk exposure, and consequently, the stock price should adjust faster to the potential losses that stem from these exposures. In other words, the market is able to "mark down" the firm's risky exposures faster. Note that eventually, over 2007 and 2008, a considerable extent of these losses is recognized through write-downs. I predict that more timely write-downs will help the market adjust for potential losses on a timelier basis since the total credit value at risk becomes evident earlier. ${ }^{6}$ This prediction implies that at any given point in time, the stock market reflects firms' exposure to risky assets more accurately for firms with timelier write-downs. ${ }^{7}$

Anecdotal evidence supports my prediction about the relation between the timeliness of write-downs and timely capital market refection of risk exposure. Consider the case of Lehman Brothers. On March 18, 2008, Lehman Brothers reported a positive earnings surprise of $\$ 0.09$ /share for the first quarter of $2008 .{ }^{8}$ Given the magnitude of the impending crisis, Lehman's write-down at the end of first quarter 2008 was clearly insufficient. In fact, Lehman filed for bankruptcy on September 15, 2008. Despite Lehman's deficient transparency, the stock market generously rewarded its positive earnings surprise. On the announcement date, Lehman's stock price jumped 46.4 percent from $\$ 31.37 /$ share to $\$ 45.93 /$ share. In other words, consistent with

\footnotetext{
${ }^{6}$ As will be evident in the empirical tests section, timelier capital market reflection of risk exposure entails a more negative cumulative stock market return (for a given dollar amount of write-downs) for any interim period during 2007 and 2008.

${ }^{7}$ This prediction requires the assumption that the stock-market is semi-strong form efficient. That is, stock prices should reflect publicly available information, but not information privately held by managers.

8 "Lehman Brothers stronger than feared." The Guardian, March 18, 2008.
} 
semi-strong-form market efficiency, Lehman's lack of transparency delayed its stock price decline. Given the discussion above, Hypothesis 2 (in alternate form) is:

H2: The stock market reflects exposure to risky assets on a timelier basis for firms with timelier write-downs.

The prediction in Hypothesis 2 is far from obvious. Credit indices such as the ABX have been used by market participants (such as Citigroup, Morgan Stanley and UBS) to mark down the values of their structured products during the crisis. ${ }^{9}$ However, as the values of these indices kept plummeting during the crisis, some participants argued that the index price levels were merely reflecting panic in the markets, and that their positions were being marked too low. Critics argued that credit indices such as the $\mathrm{ABX}$ are an unreliable guide to fair value writedowns because: a) there is a lack of liquidity in the trading of these indices, and b) these indices are not representative of the exact exposures faced by a particular institution (Fender and Scheicher 2008, Stanton and Wallace 2009). ${ }^{10}$ If the stock market views the asset valuation linked to credit indices as uninformative, then it would imply an inability to reject the null of Hypothesis 2.

\footnotetext{
${ }^{9}$ See for example, “A subprime gauge in many ways?” The Wall Street Journal, December 12, 2007.

${ }^{10}$ See also "Valuing securities: Don’t mark to Markit." The Economist, March 6, 2008.
} 


\section{Chapter 3 Data and Sample}

This study requires detailed quarterly write-down data, disaggregated by type of exposure. Specifically, I require quarterly write-down amounts with the following details: (a) type of instrument giving rise to the exposure (e.g.: Loans, Mortgage-backed Securities, Collateralized Debt Obligations, Credit Default Swaps); (b) type of underlying collateral (e.g.: Subprime, Alt-A, Prime, and Commercial Mortgages, Home Equity, Leveraged Financing); (c) credit rating and tranche details of the instrument.

The current crisis has most severely affected financial institutions; hence, I limit my sample to those institutions. The list of institutions which have reported significant credit writedowns was obtained from Bloomberg, which maintains an ongoing updated list of quarterly write-downs reported by financial institutions globally. Bloomberg's WDCI function has been widely used by observers to analyze credit losses during the crisis. ${ }^{11}$ The aggregate write-down amounts reported by Bloomberg compare well with contemporary aggregate loss estimates provided by the International Monetary Fund (IMF). For example, Bloomberg reported total write-downs of $\$ 847$ billion for US financial institutions by the end of 2008 , while the IMF estimate of the total potential write-downs by the US financial sector (including future loss estimates) at the end of 2008 was $\$ 885$ billion. ${ }^{12}$ Thus, the write-downs reported by firms included in the Bloomberg list are fairly representative of the total crisis-related losses incurred by financial institutions by the end of 2008. The Bloomberg database includes losses emanating from residential and commercial mortgage positions, and structured finance losses. Government Sponsored Enterprises (GSEs) are excluded from this study as they face a very different

\footnotetext{
${ }^{11}$ The Bloomberg WDCI functionality is extremely popular among practitioners monitoring the current crisis. See for example, "Counting write-downs replaces deals won as Wall Street's ritual." Bloomberg.com, September 2, 2008.

${ }^{12}$ International Monetary Fund, Global Financial Stability Report, October 2008.
} 
regulatory and institutional environment compared with the rest of the sample. The sample thus obtained comprises 66 firms, including publicly listed banks, brokers, and insurance companies.

Quarterly write-down data for the sample firms was then hand-collected from publicly available documents, including annual and quarterly SEC filings, investor presentations and earnings call transcripts. ${ }^{13}$ As explained earlier, write-downs refer to net credit losses recognized by financial institutions through a variety of accounting treatments, including fair value adjustments, impairment charges, realized losses on settlement of positions, and credit loss provisioning (see Chapter 5 for further discussion and analyses). The data used in this study also differs from the Bloomberg data in the following notable aspects: Bloomberg reports increases in total quarterly loan loss provisions for banks (vis-à-vis the loss provisions in the fourth quarter of 2006) as crisis-related losses. I consider increases over the corresponding quarter in 2006, rather than the fourth quarter. In addition, unless the firm explicitly attributes the increase in provision to one of the exposure categories analyzed in this study (e.g., subprime mortgages or commercial mortgages), I decompose the provision increase into: (a) the increase attributable to home equity, (b) the increase attributable to residential mortgage loans, and (c) the increase attributable to commercial mortgage loans. The decomposition is done using the following formula ${ }^{14}$ :

Increase in loan loss provision attributable to an asset-type = (Total increase in loan loss provision) $\times$ (Increase in net-charge-offs attributable to the asset-type $) \div($ Total increase in net charge-offs $)$

\footnotetext{
${ }^{13}$ An earlier version of this study directly utilized the write-down amounts compiled by Bloomberg. However, the data reported by Bloomberg was not disaggregated enough for the level of analysis used in the current version of this study.

${ }^{14}$ The decomposition based on this formula is required because loan loss provisioning amounts are often not detailed by type of exposure. However, banks provide a detailed break-up of net charge-offs in their regulatory filings (accessed through SNL Financial).
} 
This study ideally requires quarterly write-down amounts by type of collateral, with associated credit rating and tranche details of the written-down exposure. However, often firms report these details only at the net exposure level for a given quarter. In these instances, the write-down amounts are disaggregated using the exposure composition at the end of the previous quarter. For example, consider a firm which reported in quarter $t-1$ that it had $\$ 100$ million of net exposure to residential mortgage backed securities (RMBS), of which $75 \%$ had subprime collateral, while $25 \%$ had Alt-A collateral. In quarter $t$, if the firm writes down $\$ 10$ million of the RMBS and does not provide a break-up of that amount between subprime and Alt-A, then I use the portfolio composition from quarter $t-1$ to obtain the split. In this case, I would allocate $\$ 7.5$ million to subprime collateral, and $\$ 2.5$ million to Alt-A collateral. A similar procedure is used to allocate the write-down amounts to various credit rating categories and tranches (if the credit rating and tranching information for the write-down amounts is not directly provided by the firm).

The write-downs analyzed in this study are pre-tax figures. Appendix 1 provides details of the categories of write-downs by exposure type. These write-downs encompass losses pertaining to a wide range of exposures, including subprime, Alt-A, prime and commercial mortgages, structured finance instruments, leveraged loans, and exposure to monoline insurance companies, among others.

I measure the governance and incentive variables at the end of fiscal 2006. Write-downs and stock returns are measured over 2007 and 2008. The limited availability of corporate governance index data reduces the number of observations available for the multivariate analyses. Panel A of Table 1 summarizes the various sources of data used in this study. Panel B of Table 1 provides the definitions of selected variables, while Panel C provides a break-down of 
the sample by institution type. The measurement of key variables is discussed in the next chapter. 


\section{Chapter 4 Measurement of Key Variables}

\subsection{Timeliness of Write-downs}

One of the channels through which the inherent risk in subprime-related assets became apparent is the ABX.HE index (“ABX”). Since its launch by Markit Partners in January 2006, the $\mathrm{ABX}$ has become a barometer of the health of subprime mortgage-backed assets, and it serves as a key benchmark of the market for securities backed by home loans issued to borrowers with weak credit (Gorton 2008). In simple terms, the ABX is series of indices of credit default swaps written on subprime residential mortgage-backed securities of various credit qualities. ${ }^{15}$ To the extent that the index price changes are indicative of changes in the perceived credit risk of the underlying mortgage-backed securities ("MBS"), a decline in the price of the index implies the impairment of securities that are similar to, or belong to the same asset class as, the securities underlying the index.

Some of the criticisms of the use of credit indices such as the ABX are that trading in indexed derivative markets is not liquid enough, and that these indices are not representative of the securities being marked (Stanton and Wallace 2009, Fender and Scheicher 2008). These criticisms, however, are potentially muted for the approach followed in this study. As explained in greater detail below, I do not benchmark the absolute dollar amounts of quarterly write-downs, but rather the cumulative quarterly write-down as a percentage of total write-downs over 2007 and 2008. In other words, I compare the temporal distribution of accounting write-downs to the temporal distribution of the index-implied write-downs. Further, the aim of this study is to

\footnotetext{
${ }^{15}$ Specifically, each ABX series consists of a group of equally-weighted, static portfolios of CDSs referencing 20 subprime MBS transactions. There are four major series currently in use - 2006-01, 2006-02, 2007-01 and 200702. Each series references twenty new subprime MBS deals issued during the six-month period prior to index initiation. Each index series, consists of five sub-indices, each referencing different tranche levels (AAA, AA, A, $\mathrm{BBB}$, and $\mathrm{BBB}-$ ) of the same 20 underlying MBS deals. Index prices reflect investors' willingness to buy or sell protection on the basis of their views of the risk of the underlying subprime loans; these prices are quoted as a percentage of par.
} 
analyze cross-sectional differences in the timeliness of write-downs measured in the manner described below, and not to look at any single firm in isolation. Thus, my study merely assumes that transparent firms use inputs that are correlated with the credit indices in their valuation exercise.

In addition, these indices were and continue to be widely used by market participants. Notably, the ABX index is probably the only aggregated view on the value of subprime assets available to managers and investors alike (Gorton 2008). Further, there is ample anecdotal evidence to suggest that firms used the $\mathrm{ABX}$ for marking losses on subprime asset positions. ${ }^{16}$ Thus, I argue that the market indicators (in this case, the credit indices) can be used by firms as top-down checks for recording asset impairment losses. Also, while I consider the benchmarking of asset write-downs against these indices to be an innovation of my study, the general idea is consistent with Ryan (2008), who considers the lead-lag relation between ABX indices and write-downs as an issue worthy of investigation by researchers.

While the devaluation factors constructed using the $\mathrm{ABX}$ are reasonable proxies for implied losses on subprime-backed exposures such as Residential Mortgage-Backed Securities (RMBS), other credit indices are more suitable for marking positions other than subprime that underwent significant devaluation during the crisis. The list of credit indices mapped to various exposures analyzed in this study is detailed in Appendix 1. For example, I use the spreads on the CMBX index to imply impairments for commercial real-estate-backed assets, the TABX index for mezzanine Collateralized Debt Obligations (Mezz CDOs $)^{17}$, and the LCDX index for marking down exposures referenced to leveraged commercial loans (such as collateralized loan

\footnotetext{
${ }^{16}$ See for example, “A subprime gauge in many ways?” The Wall Street Journal, December 12, 2007.

${ }^{17}$ To address concerns that the TABX index reflected an even greater illiquidity component compared with the ABX, I repeat the analysis in this paper (untabulated) using the ABX index as a benchmark for mezzanine CDOs. The key inferences in this study are unaltered using this alternative series.
} 
obligations). For Alt-A and Prime positions, Markit indices are not available. Hence, I use the Bloomberg 60+ days Alt-A(Prime) Delinquency Index for Alt-A(Prime) positions. Where applicable, I use the average price (spread) across all the tranches for the ABX and the CMBX indices, and across all available versions at a given point in time. However, the results of my study are unaltered if only the BBB and BBB- tranches are used for these indices. For indices such as the CMBX, which do not have readily available prices during my sample period, I use spreads as an inverse proxy for prices.

Cumulative quarterly devaluation factors derived from these indices are used in conjunction with perfect-foresight write-downs from 2007 and 2008 to calculate the indeximplied write-downs. Specifically, the aim is to calculate the implied quarterly write-down schedule given the total write-downs during 2007 and 2008. To re-emphasize, I do not benchmark the total dollar amount of write-downs over 2007 and 2008 - rather I assume the total dollar amount of write-down as given, and benchmark the distribution of the write-down amount (or the write-down schedule) across the eight quarters. The methodology is explained below and is subsequently illustrated with the help of an example.

Step 1: For each quarter end $\tau$ during 2007 and 2008, I calculate the cumulative quarterly devaluation as a percentage of the total value lost by each of the credit indices (see Appendix 1 for the list of indices used in this study) by the end of 2008. This is the percentage of total writedowns that should have been taken by the end of quarter $\tau$, as implied by the relevant index.

$P C T \_D E V A L_{I N D E X, \tau}=\frac{D E V A L_{I N D E X, \tau}}{D E V A L_{I N D E X, T O T A L}}$

Where,

INDEX $\quad=$ one of the credit indices used in this study (refer Appendix 1).

$D E V A L_{I N D E X, \tau}=$ the cumulative devaluation of INDEX by the end of quarter $\tau$. 
DEVAL $L_{\text {INDEX,TOTAL }}=$ the total value lost by INDEX over 2007 and 2008.

$P C T \_D E V A L_{I N D E X, \tau} \quad=\quad$ the cumulative devaluation of the index by the end of quarter $\tau$ as a percentage of total value lost by the same index over 2007 and 2008.

Step 2: I map the various types of write-downs to the benchmark indices. This mapping is detailed in Appendix 1.

Step 3: Cumulative quarterly write-downs for each firm implied by each of the indices are calculated as:

INDEX-implied cumulative quarterly write-down $=($ Percentage quarterly INDEX devaluation $) \times$ (Total write-down benchmarked to INDEX)

$W D_{I N D E X, \tau} \quad=P C T_{-} D E V A L_{I N D E X, \tau} \times W D_{T_{O} T_{-} I N D E X}$

Where,

$W D_{I N D E X, \tau} \quad=$ the cumulative write-down implied by INDEX at end of quarter $\tau$.

$W D_{\text {TOT_INDEX }}=$ the total write-down during 2007 and 2008 benchmarked to INDEX.

Step 4: I compute the intra-period timeliness of write-downs for each firm-quarter as follows:

Cumulative shortage in quarterly write-downs $=($ Cumulative quarterly accounting write-down Cumulative quarterly index-implied write-down)

$D_{I F F_{\tau}}=W D_{A C T U A L, \tau}-\sum_{I N D E X} W D_{\text {INDEX, } \tau}$

Where,

$\operatorname{DIFF}_{\tau} \quad=$ the cumulative shortage in write-down at end of quarter $\tau$.

$W D_{A C T U A L, \tau}=$ the cumulative accounting write-down at end of quarter $\tau$. 
The firm-quarter level measure of timeliness is computed as follows.

$I P T_{-} W D_{\tau} \quad=\frac{D I F F_{\tau}}{W D}$

Where, $I P T_{-} W D$ is the firm-quarter level measure of timeliness of write-downs, and $W D$ is the total dollar amount of write-down over 2007 and 2008 (unscaled).

Illustration: The methodology for calculating the timeliness of write-downs is further explained with the help of an example. Consider a hypothetical firm that has exposure only to subprime residential mortgage-backed securities (i.e., the write-downs for this firm map only to the $\mathrm{ABX}$ ). Assume that the total write-down for this firm during 2007 and 2008 was $\$ 100$ million. Further, assume the following cumulative accounting write-down schedule for quarters 1 through 8: \$0 million, \$10 million, \$30 million, \$40 million, \$50 million, \$ 60 million, $\$ 70$ million, and \$100 million respectively.

Step 1: The ABX (average across all series and tranches) lost 79\% of its value by end of 2008 . Hence,

$D E V A L_{A B X \_T O T A L}=0.79$

At the end of the first quarter of 2007 , the ABX had devalued by $12 \%$. Hence, as a percentage of the total devaluation of $79 \%$, the devaluation at the end of the first quarter of 2007 was $12 \%$ divided by $79 \%=15 \%$. Hence,

$P C T \_D E V A L_{A B X, 1}=0.15$

For the purposes of our example, consider the following quarterly $\mathrm{ABX}$ devaluation factors for quarters 1 to $8: 15 \%, 12 \%, 45 \%, 72 \%, 88 \%, 84 \%, 90 \%$, and $100 \%$ respectively.

Step 2: For our hypothetical firm, all the write-downs map to the ABX index.

Step 3: Calculate the index-implied cumulative write-downs at the end of each quarter. As observed in Step 1, by the end of the first quarter, the ABX implied a write-down of $15 \%$ (as a 
percentage of total write-down during 2007 and 2008). Thus, the ABX-implied cumulative writedown at the end of the first quarter is:

$$
\begin{aligned}
W D_{A B X, 1} & =P C T_{-} D E V A L_{A B X, 1} \times W D_{T O T_{-} A B X} \\
& =0.15 \times 100=\$ 15 \text { million. }
\end{aligned}
$$

Similar calculations for the remaining quarters respectively yield the following implied writedown schedule for quarters 1 through 8: \$15 million, \$12 million, \$45 million, \$72 million, \$88 million, \$84 million, \$90 million and \$100 million.

Step 4: In our example, the cumulative quarterly shortages in accounting write-downs are $\$ 15$ million, \$2 million, \$15 million, \$32 million, \$38 million, \$24 million, \$20 million and \$0 million for quarters 1 to 8 respectively.

The firm-quarter level timeliness scores are: $-0.15,-0.02,-0.15,-0.32,-0.38,-0.24,-0.20$, and 0 respectively, for quarters 1 to 8 .

In other words, for this hypothetical firm, the accounting write-downs lag the writedowns implied by the ABX. As discussed below in Chapter 5, the hypothetical firm above is representative of a typical firm in my sample, which also has accounting write-downs that lag the index-implied write-down schedule.

\subsection{Incentives and Corporate Governance}

The tests for the determinants of timeliness of write-downs require proxies for corporate governance quality, and incentive problems between managers and investors. To measure corporate governance quality, I use the data compiled by Institutional Shareholder Services (ISS) as of fiscal year end 2006. In particular, I use the industry-adjusted Corporate Governance Quotient (CGQ) computed by ISS. The CGQ comprises the following eight categories: (a) board structure and composition, (b) audit-related issues, (c) charter and by-law provisions, (d) state of 
incorporation, (e) executive and director compensation, (f) progressive practices, and (g) director education. The variables used in creating the CGQ are detailed in the Appendix 2.

To measure incentive-alignment-related problems, I use excess annual compensation for CEOs. CEOs have a high likelihood of setting the "tone at the top" as far as risk taking and management practices are concerned. The "excess" component is measured using the residuals of a cross-sectional regression of annual CEO compensation on firm size (logarithm of number of employees), return on equity, market-to-book ratio, annual stock returns, corporate governance indicators, and industry type indicator variables. This approach is a modified version of that followed by Hong, Chen and Scheinkman (2009). All variables are measured for the 2006 fiscal year. The following regression is estimated.

$$
\begin{aligned}
\log (C O M P)_{i}= & \alpha+\beta_{1} \log (E M P)_{i}+\beta_{2} R O E_{i}+\beta_{3} M B_{i}+\beta_{4} R E T_{i}+\beta_{5} I N D E X_{-} C G Q_{i}+ \\
& \beta_{6} T Y P E_{i}+\varepsilon_{i}
\end{aligned}
$$

Where,

$\log (C O M P)_{i} \quad=$ logarithm of total CEO compensation in fiscal 2006 for firm $i$.

$\log (E M P)_{i} \quad=$ logarithm of number of employees at the end of fiscal 2006 for firm $i$.

$R O E_{i} \quad=$ the return on equity in fiscal 2006 for firm $i$.

$M B_{i} \quad=$ the market-to-book value of equity ratio at the end of fiscal 2006 for firm $i$.

$R E T_{i} \quad=$ the annual stock return in fiscal 2006 for firm $i$.

INDEX_CGQ $\quad=$ the corporate governance index (CGQ) from Institutional Shareholder's Survey.

TYPE $_{i} \quad=$ an indicator variable to control for the sub-industry of the firm (bank holding company, investment bank, insurance company, GSE, or other category).

The residual of the above regression $\left(\varepsilon_{i}\right)$, scaled by $\log (\operatorname{COMP})_{i}$, is the proxy for excess CEO compensation in $2006\left(E X_{-} C O M P_{i}\right)$. 


\section{Chapter 5 Empirical Tests}

Panel A in Table 2 provides descriptive statistics for selected variables. The firm-quarterlevel measure of the timeliness of write-downs $\left(I P T_{-} W D\right)$ is negative on average (-0.12). As explained in Chapter 4.1, this implies that the accounting write-downs lagged the index-implied write-downs. The average firm in the sample is highly leveraged (83\%) as is common for financial institutions.

Panel B in Table 2 shows the Pearson correlations. There is a significant positive correlation between corporate governance quality (INDEX_CGQ), shareholder lawsuits (SUIT), regulatory investigations $(S E C)$, and the timeliness of write-downs $\left(I P T_{-} W D\right)$. Further, size ( $\log T A)$, and leverage $(L E V)$ are significantly negatively correlated with $I P T_{-} W D$. As expected, we find a significant negative correlation between buy-and-hold abnormal returns (BHAR) and total write-downs $(W D)$. The current chapter presents the empirical tests for $\mathrm{H} 1$ and $\mathrm{H} 2$.

Since the predictions in this study are based on agency theory, I provide an initial consistency check for the existence of agency problems during the crisis (see Appendix 3 for details). In particular, I examine the relation between excess CEO compensation, corporate governance quality, and the extent of exposure to risky assets. The extent of exposure to risky assets is proxied by the total write-downs during 2007 and 2008. The results in Appendix 3 (Table A1) show that firms with greater excess CEO compensation have greater write-downs over 2007 and 2008. These results complement the findings in Hong, Chen, and Scheinkman (2009), and provide corroborative evidence that incentive problems were, to some extent, related to the exposure to risky assets. The results also lend support to the arguments that extant corporate governance and risk management mechanisms were ineffective in constraining exposure to risky assets before the crisis. 


\subsection{Lack of Timeliness in Write-downs}

Hypothesis 1(a) predicts that the write-downs undertaken by financial institutions during the crisis were not timely enough compared with the devaluations implied by the credit indices. Figure 1 compares the aggregate accounting write-down schedule (cumulative quarterly) for all the firms in the sample, with a hypothetical write-down schedule based on devaluations implied by the credit indices. Note that the total dollar amount of write-downs over 2007 and 2008 is assumed to be the same under both the schedules. The only difference between the two schedules is the quarterly distribution of the total write-down. Consistent with H1(a), I find that for each quarter between the first quarter of 2007 and the last quarter of 2008, the cumulative indeximplied write-downs are greater than the cumulative accounting write-downs. Figure 1 visually illustrates that the credit indices implied the same write-down level as the accounting writedowns at least one fiscal quarter in advance.

Table 3 provides a statistical test for the lack of timeliness predicted by H1(a). Consistent with the patterns observed in Figure 1, the differences in means of the cumulative quarterly accounting write-downs and the index-implied write-downs are negative for each of the interim quarters during 2007 and 2008. Two-tailed t-tests for the differences in means are significant at the $5 \%$ level for all but one of the cumulative quarters under consideration. To summarize, the accounting write-downs by financial institutions in my sample lagged the index-implied writedowns.

\subsection{Cross-sectional Determinants of the Timeliness of Write-downs}

Hypothesis 1(b) predicts that corporate governance quality is positively related to the timeliness of write-downs. Consistent with H1(b), in Panel B of Table 2, I observe a significant 
positive correlation between the timeliness of write-downs (IPT_WD) and corporate governance quality (INDEX_CGQ).

I use multivariate regression analysis to further examine the factors related to the timeliness of write-downs. I estimate the following cross-sectional regression:

$$
\begin{aligned}
I P T_{-} W D_{i, \tau}= & \alpha+\beta_{1} W D_{i}+\beta_{2} L E V_{i}+\beta_{3} A C L_{-} P N C_{i}+\beta_{4} A C L_{-} L_{I F E_{i}+\beta_{5} \text { TIER }_{i}+} \\
& \beta_{6} \log (T A)_{i}+\beta_{7} C O M P L E X_{i}+\beta_{8} E X_{-} C O M P_{i}+\beta_{9} I N D E X_{-} C G Q_{i}+ \\
& \beta_{10} S E C_{i, \tau}+\beta_{11} S_{U I T}+\gamma T y p e_{i}+\varepsilon_{i}
\end{aligned}
$$

Where,

$I P T_{-} W D_{i, \tau} \quad=$ the timeliness of write-downs, calculated using the procedure outlined in Chapter 4.1.

$W D_{i} \quad=$ total write-downs scaled by total assets for each firm $i$; write-downs are cumulated over 2007 and 2008, while total assets are measured at fiscal year end 2006. More positive values reflect greater accounting write-downs.

$L E V_{i} \quad=$ financial leverage, defined as total liabilities divided by total assets.

$A C L \_P N C_{i} \quad=$ the Authorized Control Level Capital Ratio for Property and Casualty insurance companies. Firms that are not subject to regulation via this capital ratio are assigned the maximum value of this ratio in the sample. This variable is measured at the end of fiscal 2006.

$A C L \_L I F E_{i} \quad=$ the Authorized Control Level Capital Ratio for Life insurance companies. Firms that are not subject to regulation via this capital ratio are assigned the maximum value of this ratio in the sample. This variable is measured at the end of fiscal 2006.

TIER $1_{i} \quad=$ the Tier I Capital Ratio for Bank Holding companies. Firms that are not subject to regulation via this capital ratio are assigned the maximum value of this ratio in the sample. This variable is measured at the end of fiscal 2006.

$\log (T A)_{i} \quad=$ logarithm of total assets at 2006 fiscal year end.

COMPLEX $_{i}=$ the percentage of total write-downs attributable to Collateralized Debt Obligations (CDOs) and Structured Investment Vehicles (SIVs). 


$$
\begin{aligned}
E X_{-} C O M P_{i}= & \text { the excess CEO compensation measure for fiscal year } 2006 \text { (refer Chapter } \\
& 4.2 \text { for details). } \\
I N D E X_{-} C G Q_{i}= & \text { the corporate governance quotient (CGQ) index from Institutional } \\
& \text { Shareholder Services. } \\
= & \text { an indicator variable that takes on a value of one if the institution is subject } \\
& \text { to a subprime-related investigation by the Securities Exchange Commission } \\
S E C_{i, \tau} & (\text { SEC) prior to the quarter under consideration, and zero otherwise. } \\
= & \text { an indicator variable that takes on a value of one if the institution is subject } \\
& \text { to credit-crisis related class action litigation prior to the quarter under } \\
& \text { consideration, and zero otherwise. } \\
= & \text { indicator variables for the type of institution (or the sub-industry to which } \\
& \text { the firm belonged), at the end of fiscal } 2006 \text { (bank holding company, } \\
& \text { insurance company, investment bank, or other categories). }
\end{aligned}
$$

In addition to corporate governance quality, I include a number of control variables that are potentially related to the timeliness of write-downs. I control for financial leverage ( $L E V)$, as firms with higher financial leverage could potentially delay their accounting write-downs to avoid violation of debt contractual constraints. Similarly, I include regulatory capital ratios (ACL_PNC, ACL_LIFE and TIER1) to control for the possibility that firms that are not well capitalized could delay their accounting write-downs to avoid violation of regulatory constraints. $E X \_C O M P$ is included as a proxy for incentive problems. COMPLEX is included to control for the possibility that firms with more complex exposures could have greater opportunity to conceal their risk and delay their accounting write-downs. Finally, SEC and SUIT are included to account for pressures arising out of regulatory investigations and shareholder lawsuits. Total write-down $(W D)$ is included as a regressor to proxy for the extent of exposure to risky assets. However, I do not have a signed prediction for the coefficient estimate on this variable, since it could reflect either of the following possibilities: (a) for firms with greater WD, the exposure is more material, and hence could be subject to greater scrutiny by insiders and outsiders, resulting in timelier 
write-downs; (b) firms with greater WD (more material exposure) could also be motivated, given agency theory, to conceal or delay the losses.

Table 4 presents the results of estimating Equation (6). Columns I to V show the results of sequentially introducing the explanatory variables in the regression. In Columns II to V, consistent with the prediction in $\mathrm{H} 1(\mathrm{~b})$, the coefficient on corporate governance quality (INDEX_CGQ) is positive and significant. The coefficients on the other explanatory variables reveal the following. In Columns I to V, I observe a significant negative relation between financial leverage $(L E V)$ and $I P T_{-} W D$, reflecting the role of financing constraints in determining the write-down policies of firms. Further, I observe some evidence that firms that were well capitalized (with higher regulatory capital ratios) are more timely than firms with tighter regulatory constraints. Specifically, I observe a positive and significant coefficient on $A C L \_P N C$ in all specifications, and a positive and significant coefficient on TIERI in Columns I and II. The coefficient on COMPLEX is negative and significant, implying that complex and opaque exposures such as CDOs and SIVs provided firms with an opportunity to delay their writedowns. Further, in Column III, the coefficient on the variable indicating a subprime-related investigation by the SEC is positive and significant, potentially reflecting the role played by regulators in flushing out the write-downs for some of the institutions. ${ }^{18}$ Finally, in Columns IV and V, I find that litigation pressure, as proxied by the existence of a crisis-related shareholder lawsuit prior to the quarter under consideration (SUIT), is significantly and positively related to the timeliness of write-downs. Consistent with Skinner (1997), the positive relation between

\footnotetext{
${ }^{18}$ However, this result is not robust to the inclusion of other control variables in Column V. A closer examination of the $S E C$ variable reveals that it is entirely subsumed by shareholder lawsuits (SUIT) and institution type indicators.
} 
SUIT and IPT_WD could reflect the fact that firms increase their transparency by taking more timely write-downs in order to limit potential litigation settlement costs. ${ }^{19}$

\subsection{Timeliness of Stock Market Adjustments}

The second hypothesis tests whether stock returns reflect risk exposure on a timelier basis for firms with more timely write-downs. I use the total dollar amount of write-downs during 2007 and 2008 as a perfect foresight proxy for the extent of exposure to risky assets. The use of total write-downs as a proxy for the extent of exposure to risky assets is motivated by the argument that firms with greater exposure to risky assets are likely to have larger total writedowns over 2007 and 2008. For a given amount of total asset write-downs, more timely adjustment involves a faster price decline, controlling for other factors. In other words, for each cumulative quarter beginning the first fiscal quarter of 2007 , I expect firms with timelier writedowns to have greater price declines per unit of write-down. Empirically, the following regression is estimated for each cumulative fiscal quarter-end:

$$
\begin{aligned}
\text { BHAR }_{i, \tau}= & \alpha+\beta_{1} W D_{i}+\beta_{2} I P T_{-} W D_{i, \tau}+\beta_{3} W D_{i} \times I P T_{-} W D_{i, \tau}+\beta_{4} O I S_{\tau}+\beta_{5} \log (T A)_{i}+ \\
& \beta_{6} I N D E X_{-} C G Q_{i}+\varepsilon_{i, \tau}
\end{aligned}
$$

Where,

$B H A R_{i, \tau} \quad=$ the buy-and-hold abnormal return for firm $i$ up to the end of quarter $\tau(\tau=1$, $2, \ldots .8$ ); abnormal returns are calculated as the raw returns minus the return on the value-weighted CRSP market portfolio.

$W D_{i} \quad=$ the total write-downs scaled by total assets for each firm $i$; write-downs are cumulated over 2007 and 2008, while total assets are measured as of fiscal year end 2006. More positive values reflect greater write-downs.

\footnotetext{
${ }^{19}$ In addition to being statistically significant, the test variables and control variables are also economically significant. Specifically, for Column V of Table 4, a one standard deviation increase in INDEX_CGQ, LEV, COMPLEX, and SUIT increases the dependent variable, IPT_WD, by $0.1,0.33,0.12$ and 0.07 standard deviations respectively.
} 


$$
\begin{aligned}
I P T_{-} W D_{i, \tau}= & \text { the timeliness of write-downs, calculated using the procedure outlined in } \\
& \text { Chapter } 4.1 . \\
= & \text { the change in the OIS spread over the BHAR computation window; defined } \\
& \text { in Table 1, Panel } \mathrm{B} \text { as the spread between the 3-month LIBOR and the } \\
& \text { comparable overnight index swap rates (OIS), i.e. future expected policy } \\
& \text { rates (the Federal Funds rate in the U.S.) over the same horizon; OIS is used } \\
& \text { as a proxy for general counterparty risk and liquidity factors in inter-bank } \\
& \text { lending. } \\
= & \text { logarithm of total assets at } 2006 \text { fiscal year end } \\
\log (T A)_{i} \quad & \text { the corporate governance quotient (CGQ) index from Institutional } \\
I N D E X_{-} C G Q_{i}= & \text { Shareholder Services. }
\end{aligned}
$$

Note that more positive values of $W D$ reflect larger write-downs. Thus, the relation between $W D$ and BHAR is expected to be negative (i.e. larger write-downs are ceteris paribus related to more negative cumulative stock returns). According to $\mathrm{H} 2$, at a given point in time, this negative mapping between $W D$ and $B H A R$ would be enhanced if the write-downs are timely. More timely write-downs correspond to more positive values of $I P T_{-} W D$. Thus, in Equation (7), a negative coefficient on the interaction term between $I P T_{-} W D$ and $W D\left(\beta_{3}\right)$ implies that on any quarter-end $(\tau)$ during 2007 and 2008, the cumulative stock returns reflect a greater portion of institutions' exposure to risky assets for firms with more timely write-downs. In other words, conditioning on the pricing effect of $W D$, the market is able to reflect the risk exposure of firms (proxied by total write-downs during 2007 and 2008) on a timelier basis. Thus, under H2, I expect $\beta_{3}$ to be negative for each of the cumulative quarterly regressions.

Given the research design in Equation (7), pooling the observations results in the dependent variable (BHAR) being measured using overlapping time horizons. This gives rise to correlation in residuals at the firm level across all the cumulative quarters. Further, the residuals could also potentially be correlated across different firms for a given cumulative quarter. Due to 
potentially correlated residuals across observations at the firm level and the cumulative quarter level, ordinary least squares (OLS) standard errors may be biased. Hence, the standard-errors of the pooled regressions are clustered by firm and quarter to correct for both time-series and crosssectional dependence (Petersen 2009). However, to further mitigate the econometric concerns regarding the pooled specification, the results of individual cumulative regressions are shown alongside the pooled specification.

The results of estimating Equation (7) are presented in Table 5. Panel A presents cumulative quarterly and pooled regressions using Ordinary Least Squares (OLS) regressions. The results reveal that the estimated coefficient on the interaction term between $I P T_{-} W D$ and $W D\left(\beta_{3}\right)$ is negative and statistically significant, indicating that timely write-downs enable the stock market to assess the riskiness of these institutions' exposures, and to mark down the exposures on a timely basis. Specifically, $\beta_{3}$ is negative and significant in 6 out of 7 cumulative quarterly regressions in Panel $A .{ }^{20}$ Further, $\beta_{3}$ is negative and statistically significant in the pooled specification as well. Also, note the negative and significant coefficient on the main effect of write-downs $\left(\beta_{1}\right)$ in all the panels. In other words, the results in Panel A of Table 5 confirm my prediction that cumulative stock returns on a given quarter end are more negative for firms with greater exposure to risky assets, and are even more negative for firms with timelier write-downs. Finally, in the pooled regression, the negative and significant coefficient $\left(\beta_{4}\right)$ on OIS implies that inter-bank liquidity and general risk factors are related in a predictable way to stock returns during the period. ${ }^{21,22}$

\footnotetext{
${ }^{20}$ Since IPT_WD is zero by construction for the last quarter of 2008 , cumulative quarterly regressions can be run only for the first seven cumulative quarters (up to and including the third quarter of 2008).

${ }^{21}$ Note that the variable OIS is measured at the cumulative quarter level and takes on the same value for all firms in cumulative quarterly regressions. Hence, in cumulative quarterly regressions, including OIS has the effect of merely adding a constant to the intercept. In the pooled regressions, OIS varies over time and has the same effect as does including quarter fixed effects. Thus, OIS is included in the pooled regressions only.
} 
One of the concerns with the research design outlined in Equation (7) is the potential endogeneity between stock returns, timeliness of write-downs, and total write-downs. In other words, BHAR, IPT_WD and WD could be driven by the same unobserved factors. To address this concern, I conduct an instrumental variables (I.V.) regression analysis. In this analysis, IPT_WD, $W D$, and $I P T_{-} W D^{*} W D$ are treated as endogenous variables. The explanatory variables in Equation (A1) in Appendix 3 and Equation (6) are the instrumental variables. ${ }^{23}$ Notice that all the instruments are determined in time periods prior to the determination of the endogenous variables, so concerns of reverse causality are mitigated. The first stage adjusted $\mathrm{R}^{2} \mathrm{~s}$ for $I P T_{-} W D$ and WD are reasonably high (11\% and $25 \%$ respectively). The results of the I.V. estimation are presented in Panel B of Table 5. We observe that the coefficient $\beta_{3}$ remains negative and significant in the pooled specification. However, the results of the individual cumulative quarterly regressions are statistically weaker than the OLS results.

\subsection{Additional Analyses}

\subsubsection{Ex ante Measure of Transparency Constructed using the 2006 Annual Report Disclosures}

This study focuses on timely write-downs by financial institutions as an indicator of financial reporting transparency. An alternate way of informing investors about exposure to risky assets is through ex ante disclosures in annual reports. Hence, in additional analyses, I employ a self-constructed disclosure index based on best practices observed by the SSG report (Senior Supervisors Group's report to the Chairman of the Financial Stability Forum, 2008). This report

\footnotetext{
${ }^{22}$ A potential concern with the specification in Equation (7) is that the regressors, $W D, I P T_{-} W D$, and $W D \times I P T_{-} W D$ are all derived using write-downs and could lead to collinearity problems. However, we observe in Table 2, Panel B that the correlation between $W D$ and $I P T_{-} W D$ is very low and statistically insignificant $(-0.06)$, mitigating multicollinearity concerns.

${ }^{23}$ I consider these to be the instrumental variables because they are predicted to be related directly to the endogenous variables. However, they are potentially related to the dependent variable (BHAR) only indirectly (through their effect on the $I P T_{-} W D$ and $W D$ ).
} 
was prepared for and submitted to the Chairman of the Financial Stability Forum of the Bank of International Settlements in 2008. SSG comprises senior financial supervisors from seven countries (United States, Canada, France, Germany, Japan, Switzerland, and the United Kingdom). The U.S. is represented by the Securities and Exchange Commission (SEC) and the Federal Reserve Board of New York (FRBNY). This index is made possible through data collected from 2006 fiscal year-end annual reports. ${ }^{24}$ The items used in the index are listed in Appendix 4.

The broad categories comprise disclosures pertaining to special purpose entities (SPEs), collateralized debt obligations (CDOs), exposure to other subprime and Alt-A securities not in CDOs, commercial mortgage-backed securities (CMBS), and leveraged finance. Within each of these categories, firms are evaluated on the basis of the granularity of disclosures about the nature of the exposure and the underlying collateral. If the relevant information is available (unavailable) in the 2006 annual report, a score of one (zero) is assigned to a line item. Individual line item scores are then summed to calculate the raw score for each firm. In some cases, non-disclosure could imply that the item is not applicable to that firm. Hence, I convert the raw scores into percentages by dividing the raw scores by the maximum possible score for each firm given the nature of its exposures (revealed ex post through various types of write-downs).

Table 6 presents the results of estimating Equation (7) using the disclosure index (DISCL2006) as a measure of transparency instead of IPT_WD. The results show that the estimated coefficient on the interaction term between DISCL2006 and WD $\left(\beta_{3}\right)$ is negative and statistically significant, indicating that improved disclosure enables the stock market to reflect the risk positions of firms on a timelier basis. Specifically, $\beta_{3}$ is significantly negative in 6 out of

\footnotetext{
${ }^{24}$ The approach used is similar to that followed by Bhat (2008a, 2008b). However, Bhat focuses on disclosures concerning risk exposure for the bank as a whole, while I concentrate solely on the institutions' disclosure pertaining to selected credit exposures.
} 
8 cumulative quarterly regressions, and is significantly negative in the pooled specification as well. To summarize, the results in Table 6 corroborate my prediction that transparent financial reporting helps the stock market to reflect risk exposure on a timely basis. ${ }^{25}$

\subsubsection{Alternative Market-based Measure of Exposure to Risky Assets}

The dependent variable in the tests for $\mathrm{H} 2$ is buy and hold abnormal returns from the beginning of 2007 to the end of a particular quarter under consideration. In additional analyses, I use another market-based dependent variable - the sensitivity of stock returns to percentage changes in price of the $\mathrm{ABX}$ index (average of all versions and tranches). The regression approach to calculate this sensitivity measure $\left(A B X \_B E T A\right)$ is outlined in Appendix 5, and is similar to Knaup and Wagner (2008), who use the more general CDX investment grade and cross-over indices to arrive at a market-based measure of credit risk. ${ }^{26,27}$ This method is based on the information about credit quality impounded in share prices. As a market-based measure of credit quality, this measure is forward-looking and incorporates information quickly. In the context of my study, the sensitivity of stock returns to changes in the ABX index can be interpreted as the stock market's assessment of a firm's exposure to subprime-related risk. For each firm in the sample, I estimate the sensitivities $\left(A B X \_B E T A\right)$ on a rolling basis using data from (and including) the fourth quarter of 2006 up to quarter $\tau$ (quarter $\tau$ being the quarter under consideration). I estimate the following regression, which is similar to Equation (7), except that the dependent variable is $A B X \_B E T A_{i, \tau}$ :

\footnotetext{
${ }^{25}$ Note that higher values of both the variables, IPT_WD (in Table 5), and DISCL2006 (in Table 6), imply greater financial reporting transparency.

${ }^{26}$ This analysis relates to the literature on the association between financial reporting disclosures and market-based measures of risk (Beaver, Kettler, and Scholes 1970, Wong 2000, Jorion 2002).

${ }^{27}$ I do not use the CDX indices in this study as they reference a broad category of firms, including non-financial corporations. The ABX index is used instead since it is more directly related to risk exposures during the financial crisis.
} 


$$
\begin{aligned}
A B X \_B E T A_{i, \tau}= & \alpha+\beta_{1} W D_{i}+\beta_{2} I P T_{-} W D_{i}+\beta_{3} W D_{i, \tau} \times I P T_{-} W D_{i, \tau}+\beta_{4} O I S_{\tau}+ \\
& \beta_{5} \log (T A)_{i}+\beta_{6} I N D E X_{-} C G Q_{i}+\varepsilon_{i, \tau}
\end{aligned}
$$

The cumulative quarterly and pooled regression results are presented in Table $7 .{ }^{28}$ In Equation (8), a positive coefficient on the interaction term between $I P T_{-} W D$ and $W D\left(\beta_{3}\right)$ implies that on any quarter-end $(\tau)$ during 2007 and 2008, the $A B X \_B E T A$ reflects a greater portion of institutions' exposure to risky assets for firms with more timely write-downs. In other words, the stock market is able to reflect the risk exposure of firms (proxied by total write-downs during 2007 and 2008) on a timelier basis. Thus, under H2, I expect $\beta_{3}$ to be positive for each of the cumulative quarterly regressions. In other words, $A B X \_B E T A$ is more informative (about exposure to risky assets) for firms with timelier write-downs.

The results of estimating Equation (8) are presented in Table 7. The results show that the estimated coefficient on the interaction term between $I P T_{-} W D$ and $W D\left(\beta_{3}\right)$ is positive and statistically significant, indicating that timely write-downs enable the market to assess the riskiness of these institutions' exposures on a timely basis. Specifically, $\beta_{3}$ is positive and significant in 3 out of 6 cumulative quarterly regressions. Further, $\beta_{3}$ is positive and statistically significant in the pooled specification as well. Also, note the positive and significant coefficient on the main effect of write-downs $\left(\beta_{1}\right)$. Thus, the results in Table 7 corroborate my findings in Table 5 that the stock market reflects the exposure to risky assets on a timelier basis for firms with more timely write-downs. ${ }^{29}$

\subsubsection{Additional Controls for Exposure-Specificity}

\footnotetext{
${ }^{28}$ Note that the since $A B X \_B E T A$ is measured up to the quarter under consideration, the cumulative quarterly regression for the first quarter of 2007 is not included since the ABX index did not exhibit significant variation until then. Further, since $I P T_{-} W D$ is zero by construction for the last quarter of 2008, cumulative quarterly regressions can be run only up to and including the third quarter of 2008.

${ }^{29}$ In untabulated analyses, I replace IPT_WD by DISCL2006 and observe similar results.
} 
As discussed in Chapter 1, the financial crisis evolved in waves (Ryan 2008), with different asset classes being affected with greater severity at different points in time. For example, Subprime and Home Equity positions were affected earlier than commercial and prime mortgage positions. The approach followed in this study to measure the timeliness of writedowns confronts this issue by using asset-specific credit indices to benchmark the accounting write-downs taken by financial institutions (as opposed to an aggregate firm-level measure such as stock returns). However, there is a potential concern that available credit indices do not entirely capture the fineness of a firm's balance sheet composition, or the specificity of its exposure to affected asset classes. I address this concern by including a number of additional control variables.

The following variables are included as additional controls for the riskiness/seniority of firm exposures. The variables are constructed so that higher values indicate lower risk.

(a) GEOGRAPHY: The percentage of total mortgage loans that the institution did not originate in California or Florida (higher risk geographies). Data are obtained from the HMDA (Home Mortgage Disclosure Act) database accessed through SNL financial. Due to availability constraints, data from the year 2007 is used to construct this variable.

(b) RATED_A+: Percentage of write-downs taken during the quarter which arose from exposures that were rated at least A, either by a credit rating agency or internally by the firm. Data are hand-collected from quarterly SEC filings, investor presentations, and earnings call transcripts.

(c) SINGLE_FAMILY: Ratio of single (1-4) family closed-ended mortgage loans to total mortgage loans held in portfolio at the beginning of a given quarter. The 
premise is that multi-family loans, junior-liens, and home equity lines of credit are riskier than single-family closed-ended mortgage loans. Data are obtained from bank regulatory filings accessed through SNL Financial.

(d) $C D O \_H G$ : Percentage of write-downs pertaining to CDOs taken by a firm during the quarter which arose from high grade (more senior to mezzanine) exposures. Data are hand-collected from quarterly SEC filings, investor presentations, and earnings call transcripts.

(e) $C D O \_S Q$ : One minus the percentage of write-downs pertaining to CDOs taken by a firm during the quarter which arose from CDO-Squareds (CDOs which have CDOs as collateral) exposures. Data are hand-collected from quarterly SEC filings, investor presentations, and earnings call transcripts.

(f) LESS_RISKY: The first principal component of the variables GEOGRAPHY, RATED_A+, SINGLE_FAMILY, CDO_HG,CDO_SQ.

(g) MONOLINE: Percentage of write-downs taken by a firm during the quarter which arose from credit valuation adjustments on account of ineffective monoline hedges. Data are hand-collected from quarterly SEC filings, investor presentations, and earnings call transcripts.

Column I of Table 8, Panel A presents the results of including the additional control variables (a) to (e). While the control variables load in the predicted direction (negative), only GEOGRAPHY and CDO_HG are statistically significant. Column II presents the results with the first principal component of these additional control variables, LESS_RISKY, which is negative and significant. ${ }^{30}$ These results are consistent with the notion that the crisis evolved in waves,

\footnotetext{
${ }^{30}$ Principal Component Analysis is used to transform these correlated variables into a single variable that captures the same construct — LESS RISKY. The Pearson correlation between CDO_HG and CDO_SQ is negative and
} 
with the presumably less risky exposures being affected later. Consequently, they were also written down later. Note, however, that the inclusion of these additional controls does not affect the main cross-sectional results pertaining to the determinants of the timeliness of write-downs (described earlier in Table 4). Specifically, I continue to find support for the hypothesis (H1b) that corporate governance quality is positively and significantly related to the timeliness of writedowns. I also repeat the analysis in Table 5 (pertaining to the timeliness of stock market reflection of exposure to risky assets) after including $L E S S \_R I S K Y$ as an additional control variable. Consistent with $\mathrm{H} 2$, in untabulated results, I continue to observe a negative and significant coefficient on the interaction term IPT_WD*WD.

Panel B of Table 8 documents the cross-sectional results with an additional control for credit value adjustments arising due to ineffective monoline hedges. The argument is that firms are likely to wait longer for a strong signal of monoline ineffectiveness (such as a credit rating downgrade) before deeming the hedge to be ineffective. Hence, these write-downs could be inherently less timely than the devaluations implied by benchmark credit spreads. Consistent with this argument, I find that MONOLINE loads negatively and significantly. As earlier, I continue to find support for the hypothesis (H1b) that corporate governance quality is positively and significantly related to the timeliness of write-downs. ${ }^{31}$

\subsubsection{Additional Controls for Accounting Treatment}

Loss recognition during the crisis was achieved through a variety of accounting treatments - including fair value adjustments, impairment charges, realized losses on settlement of positions, and credit loss provisioning. The dataset used in this study includes losses arising

significant, while the correlations between GEOGRAPHY, SINGLE_FAMILY, and RATED_A+ are positive and significant.

${ }^{31}$ I do not repeat the Table 5 analysis (H2) using MONOLINE as an additional control variable because the procedure for measuring the key test variable $\left(I P T_{-} W D\right)$ incorporates the appropriate benchmark credit index for the monoline category (refer to Appendix 1). 
from all of the above types of accounting treatments. A potential concern is that certain accounting treatments are less timely compared to fair value accounting, either by GAAP mandate or as a result of industry practice. For example, impairment accounting for held-forinvestment instruments requires that the impairments be deemed "other-than-temporary impairments (OTTI)" before being charged to the income statement, making them inherently less timely than charges recognized via fair value accounting. Similarly, loan loss provisioning for homogenous loans is often done on the basis of historical credit quality indicators, rendering them less timely than fair value losses. In addition to valuation adjustments, credit losses can also arise on account of sale of assets or settlement of positions with counterparties. It is possible that earlier in the crisis period, firms considered the credit market dislocations to be temporary, and consequently, delayed the settlement of their positions. This would make the realized credit losses to appear less timely than fair value losses using the methodology outlined in Chapter 4.

To address these concerns, I further control for the nature of accounting treatment that was used to recognize a particular credit loss during the quarter. Specifically, I construct the following variables to capture potentially less timely accounting treatments.

(a) IMPAIRMENT: Percentage of write-downs taken by a firm during the quarter which arose from the application of impairment accounting. Data are handcollected from quarterly SEC filings, investor presentations, and earnings call transcripts.

(b) REALIZED: Percentage of write-downs taken by a firm during the quarter which arose from losses on sales of assets or unfavorable settlement of positions. Data are hand-collected from quarterly SEC filings, investor presentations, and earnings call transcripts. 
(c) PROVISION: Percentage of write-downs taken by a firm during the quarter which arose from the application of loan loss provisioning. Data collection for loan loss provisions is detailed in Chapter 3.

Panel $\mathrm{C}$ of Table 8 presents the results of estimating Equation (6) with the inclusion of these additional control variables. All the variables have a predicted negative sign. I observe that while the coefficient on PROVISION is negative and significant, the coefficients on IMPAIRMENT and REALIZED are insignificant. Note that despite the inclusion of these additional controls, I continue to find support for the hypothesis (H1b) that corporate governance quality is positively and significantly related to the timeliness of write-downs.

\subsubsection{Additional Control for Ex ante Disclosure Quality in Tests of H2 (Timeliness of Stock Market Reflection of Exposure to Risky Assets)}

A maintained assumption in the regressions presented in Table 5 is that firms convey incremental, value-relevant information to market participants through timely write-downs. Alternatively, if the risk exposure disclosures provided by firms were informative enough, then market participants could derive the implied write-downs themselves without relying on the firms' accounting write-downs. In other words, a rich ex ante disclosure environment would make timely write-downs uninformative. To test this, I repeat the analysis in Table 5 after controlling for ex ante disclosure scores (DISCL2006). Untabulated results indicate that the interaction term $I P T_{-} W D^{*} W D$ remains negative and significant. In other words, the ex ante disclosure environment during the crisis was not rich enough to obviate the usefulness of timely accounting write-downs.

\subsubsection{Alternate Explanations}


This section discusses alternative explanations for the determinants of the timeliness of write-downs.

Signaling: The results in this study suggest that, on average, firms delayed credit loss recognition during the crisis. However, there is a possibility that some firms could be more timely in their accounting write-downs to signal better-than-expected asset quality. This prediction can be tested by analyzing the coefficient on the variable $L E S S \_R I S K Y$ in Table 8, Panel A. Under the signaling prediction, we would expect firms with better (or less risky) exposures to have timelier write-downs. However, the evidence is contrary to this prediction - I find that firms with less risky exposures have less timely write-downs. While the results in Table 8 are inconsistent with the signaling prediction, they are consistent with the notion that the financial crisis evolved in waves, with certain riskier exposures (such as subprime positions) being affected earlier than the others.

Valuation uncertainty: Loss recognition during the crisis could also be affected by uncertainty associated with the measurement and valuation of credit risky positions, especially those pertaining to complex and illiquid instruments. Under this explanation, it is likely that positions associated with greater valuation uncertainty (such as CDOs and SIVs) were written down later. I test this prediction by analyzing the coefficient on the variable COMPLEX in Table 4. As discussed earlier, the negative coefficient on COMPLEX suggests that more complex exposures were written down later. This result could be viewed as being consistent with the valuation uncertainty explanation - that the valuation of complex positions such as CDOs and SIVs was highly uncertain, and hence, managers waited for some of the uncertainty to resolve before marking the positions down. However, since the cross-sectional results concerning the effect of corporate governance quality, litigation pressure, and regulatory investigations on the 
timeliness of write-downs continue to hold despite this and other controls, it is unlikely that valuation uncertainty alone can explain the lack of timeliness of write-downs during the crisis. 


\section{Chapter 6 Conclusions}

This study empirically examines the timeliness of write-downs by U.S. financial institutions affected by the ongoing financial crisis. Timeliness of write-downs is measured by benchmarking the quarterly accounting write-down schedule with the devaluation schedule implied by credit indices such as the ABX. The empirical tests reveal the following. First, I find that accounting write-downs are less timely than the devaluations implied by credit indices. Second, I examine the cross-sectional determinants of the timeliness of write-downs and document that corporate governance quality is positively related to the timeliness of writedowns. Third, I show that for firms with timelier write-downs, exposure to risky assets is reflected faster in stock returns. This result lends support to the claim that credit indices such as the ABX provide a useful check for firms to benchmark their losses on risky exposures during the crisis. In supplementary analysis, I document that the stock market reflects risk exposure on a timelier basis for firms that are ex ante more transparent about their exposure to risky assets (using a disclosure index based on 2006 annual report disclosures).

This thesis makes a number of contributions to the academic and practitioner literatures.

First, I contribute to the ongoing debate concerning financial reporting transparency during the current financial crisis. While the empirical tests are specific to the crisis, the conclusions drawn from this study may have a wider relevance, particularly to researchers and policy makers interested in analyzing transparency and risk management in financial institutions. Second, I add to the literature on the consequences of financial reporting transparency by examining the effect of a specific transparency measure (the timeliness of write-downs) on a specific outcome variable (the timeliness of stock price adjustment). Third, this thesis represents a contribution to the literature on the timeliness of capital market adjustments to accounting information, and to the literature on timely loss recognition (or conditional conservatism). Finally, my finding that 
the stock-market reflects subprime exposure on a timelier basis for firms with timelier writedowns contributes to the literature that analyzes the relation between financial disclosures and market-based measures of risk.

As with almost every empirical study, this thesis too is subject to caveats that the reader should be careful about while interpreting the results: (a) despite attempts in this study to account for liquidity-related and systemic declines in the price levels of the credit indices, there is an underlying assumption that at least part of the price decline of these indices was driven by fundamental (unobservable) credit losses. This assumption seems reasonable given the evidence in Fender and Scheicher (2008) that in addition to liquidity factors, mortgage market fundamentals also contributed to the $\mathrm{ABX}$ price declines, and the fact that the price levels of the junior tranches of indices such as the ABX remain severely depressed as of August 2010. If the price declines were solely driven by liquidity-related factors, then one would have expected to see a complete reversal of these declines as liquidity pressures eased on account of various government interventions such as the Troubled Asset Relief Program (see also the related discussion in Laux and Laux 2009b); (b) this study uses total write-downs over 2007 and 2008 as a perfect foresight proxy for the extent of exposure to credit-risky assets. The choice of this perfect foresight measure is based on conceptual and practical grounds. Conceptually, this is a reasonable proxy, since firms with greater ex ante exposure to credit-risky assets are likely to have greater ex post accounting write-downs. While it is beneficial to have an ex ante measure of exposure to credit risky assets, given the complexity of the exposures, it is practically very difficult to construct these ex ante measures. 


\section{References}

Ajinkya, B., S. Bhojraj, and P. Sengupta. 2005. "The association between outside directors, institutional investors and the properties of management earnings forecasts." Journal of Accounting Research 43(3): 343-376.

Allen, F., and Carletti, E. 2008. "Mark-to-market accounting and liquidity pricing." Journal of Accounting and Economics 45, 358-378.

American Bankers Association. 2008. Letter to the SEC. September 23, 2008.

Alford, A., R. Leftwich, and M. Zmijewski. 1993. "The relative informativeness of accounting disclosures in different countries.” Journal of Accounting Research 31: 183-223.

Ali, A., T. Chen, and S. Radhakrishnan. 2007. "Corporate disclosures by family firms." Journal of Accounting and Economics 44: 238-286.

Ball, R. (2008). "Don't shoot the messenger ... or ignore the message". Note, University of Chicago.

Ball, R., and P. Brown. 1968. "An empirical evaluation of accounting income numbers." Journal of Accounting Research 6: 159-178

Ball, R., A. Robin and J. Wu. 2003. "Incentives versus standards: Properties of accounting income in four East Asia countries." Journal of Accounting and Economics 36: 235-270

Ball, R., and L. Shivakumar. 2005. "The role of accruals in asymmetrically timely gain and loss recognition.” Journal of Accounting Research 44(2): 207-242

Basel Committee on Banking Supervision. 2006. "Basel II: International Convergence of Capital Measurement and Capital Standards: A Revised Framework”. 2006.

Basu, S. 1997. "The Conservatism principle and the asymmetric timeliness of earnings." Journal of Accounting and Economics 24: 3-37.

Beaver, W., P. Kettler, and M. Scholes. 1970. "The association between market determined and accounting determined risk measures." The Accounting Review 45 (October): 654-82.

Bebchuk, L. , and J. Fried. 2003."Executive compensation as an agency problem.” Journal of Economic Perspectives 17: 71-92.

Berger, P., and R. Hann. 2007. "Segment profitability and the proprietary and agency costs of disclosure." The Accounting Review 82: 869-906.

Bernanke, B. 2009. Financial innovation and consumer protection: A speech at the Federal Reserve System's Sixth Biennial Community Affairs Research Conference, Washington, DC, April 17. 2009. 
Bhat, G. 2008a. "Risk relevance of fair value gains and losses, and the impact of disclosure and corporate governance.” Working Paper, Washington University.

Bhat, G. 2008b. "Impact of disclosure and corporate governance on the association between fair value gains and losses and stock returns in the commercial banking industry." Working Paper, Washington University.

Bicksler, J. 2008. "The subprime mortgage debacle and its linkages to corporate governance." International Journal of Disclosure and Governance 5: 295-300.

Bushman, R., J. Piotroski and A. Smith. 2004. "What determines corporate transparency?" Journal of Accounting Research 42: 207-252

Bushman R., A. Smith. and R. Wittenberg-Moerman. 2008. "Price discovery and dissemination of private information by loan syndicate participants." Working Paper, University of Chicago.

Butler, M., A. Kraft, and I. Weiss. 2007. "The effect of reporting frequency on the timeliness of earnings: the cases of voluntary and mandatory interim reports." Journal of Accounting and Economics 43:181-217

Callen, J., M. Khan, and H. Lu. 2009. “Accounting quality, stock price delay and future stock returns." Working Paper, University of Toronto.

American Institute of Certified Public Accountants - Center for Audit Quality. 2007.

"Measurements of fair value in illiquid (or less liquid) markets." October 3, 2007.

Core, J., R. Holthausen., and D. Larcker. 1999. "Corporate governance, CEO compensation, and firm performance.” Journal of Financial Economics 51: 371-406.

Davidson, W., P. Jiraporn, Y. Kim, and M. Singh. 2006. "Corporate governance, shareholder rights and firm diversification: An empirical analysis." Journal of Banking and Finance 30: 947-63.

Dickey, J., M. King, and K. Shih. 2008. "Subprime-related securities litigation: Where do we go from here?" Insights: The Corporate Securities and Law Advisor 22(4): 2-10.

The Economist. 2008. "Valuing securities: Don’t mark to Markit.” March 6, 2008.

Fama, E., L. Fischer, M. Jensen and R. Roll. 1969. "The adjustment of stock prices to new information." International Economic Review 10: 1-21.

Fender, I. and M. Scheicher.2008. “The ABX: How do the markets price subprime risk?” BIS Quarterly Review September: 67-81. 
Financial Accounting Standards Board. Continuously Updated. FASB Pronouncements and EITF Abstracts, Norwalk, CT. http://72.3.243.42/st/.

Forbes, S. 2009. “End mark-to-market.” Forbes.com, March 29, 2009.

Gorton, G. 2008. “The Subprime Panic.” European Financial Management, forthcoming.

Healy, P. 1985. "The effect of bonus schemes on accounting decisions." Journal of Accounting and Economics 7: 85-107.

Hong, H., I-H. Cheng, and J. Scheinkman. 2009. "Yesterday's Heroes: Compensation and Creative Risk-Taking." Working paper, Princeton University.

Hope, O., and W. Thomas. 2008. "Managerial empire building and firm disclosure." Journal of Accounting Research Vol. 46 (3): 591-626.

Hou, K. and T. Moskowitz. 2005. "Market frictions, price delay and the cross-section of expected returns." Review of Financial Studies 18 (3): 981-1020.

Hull, J. 2009. "The Credit Crunch of 2007: What went wrong? Why? What lessons can be learned" Journal of Credit Risk, forthcoming.

Hutton, A. 2007. "A discussion of corporate disclosures by family firms." Journal of Accounting and Economics 44: 287-297.

Jorion, P. 2002. "How informative are Value-at-Risk disclosures?" The Accounting Review 77(4): 911-931.

Jensen, M., and W. Meckling. 1976. "Theory of the firm: Managerial behavior, agency costs and ownership structure.” Journal of Financial Economics 3: 305-360.

Karamanou, I., and N. Vafeas. 2005. "The association between corporate boards, audit committees, and management earnings forecasts: An empirical analysis." Journal of Accounting Research 43(3): 453-486.

Kasznik, R., and B. Lev. 1995. "To warn or not to warn: Management disclosures in the face of an earnings surprise." The Accounting Review 70: 113-34.

Khanna, T., K. Palepu and S. Srinivasan. 2004. "Disclosure practices of foreign companies interacting with US markets.” Journal of Accounting Research 42: 475-508.

Kirkpatrick, G. 2009. "The corporate governance lessons from the financial crisis." Working Paper, OECD. 
Knaup, M., and W. Wagner. 2008. "Market-based measure of credit quality and banks' Performance during the Subprime Crisis.” Working Paper.

Landsman, W. 2007. "Is Fair Value Accounting Information Relevant and Reliable? Evidence from Capital Market Research". Accounting and Business Research January 2007.

Laux, C. and C. Leuz. 2009a. "The crisis of fair-value accounting: Making sense of the recent debate." Accounting, Organizations and Society, forthcoming.

Laux, C. and C. Leuz. 2009b. "Did fair-value accounting contribute to the crisis." NBER Working Paper No. w15515.

Mollenkamp, C., S. Ng, and S. Patterson, "A subprime gauge in many ways?" The Wall Street Journal December 12, 2007.

Morgan, D. P. 2002. "Rating Banks: Risk and Uncertainty in an Opaque Industry", American Economic Review, 92(4): 874-88.

Onaran, Y. 2008. "Counting write-downs replaces deals won as Wall Street's ritual." Bloomberg.com September 2, 2008.

Petersen, M. 2009. "Estimating standard errors in finance panel data sets: Comparing approaches." Review of Financial Studies 22: 435-480.

Plantin, G., Sapra, H., \& Shin, H.S. 2008. Marking-to-market: panacea or pandora's box? Journal of Accounting Research 46, 435-460.

Rajan, R. 2006. "Has finance made the world riskier?" European Financial Management 12(4): 499-533.

Ryan, S. 2008. "Accounting in and for the Subprime Crisis." The Accounting Review 83: $1605-$ 1639.

Schwarz, S.L. 2008. "Disclosure's Failure during the Subprime Crisis". Working Paper, Duke University Law School.

Senior Supervisors Group. "Leading-practice disclosures on selected exposures." Report to the Financial Stability Forum, April 11, 2008.

Skinner, D. 1997. "Earnings disclosures and stockholder law suits." Journal of Accounting and Economics 23: 249-82.

Stanton, R. and N. Wallace. 2009. "ABX.HE indexed credit default swaps and the valuation of subprime MBS." Fisher Center for Real Estate \& Urban Economics. Fisher Center Working Papers: Paper 312. 
Strebel, P. 2008. "Boards out of depth in subprime? What bank boards need to avoid lending excesses." Mimeo, IMD, Switzerland.

Turner, L. 2008. "Banks want to shoot the messenger over fair value rules." Financial Times October 2, 2008.

Veron, N. 2008. "Fair value accounting is the wrong scapegoat for this crisis." European Accounting Review 5, 63-69.

Whalen, R.C. 2008. "The subprime crisis - causes, effect and consequences." Working Paper, Networks Financial Institute.

Wong, F. 2000. "The association between SFAS No. 119 derivatives disclosures and the foreign exchange risk exposure of manufacturing firms." Journal of Accounting Research 38: $387-417$

Wray, R. 2008. "Lehman Brothers stronger than feared.” The Guardian March 18, 2008. 


\section{Appendix 1: Mapping between Types of Write-downs and Credit Index Benchmarks}

This table provides a list of the types of write-downs, and their mapping to the corresponding benchmark indices. A particular type of write-down is mapped to an index if the exposure underlying the index is similar to the writtendown exposure.

\begin{tabular}{ll}
\hline \hline $\begin{array}{l}\text { Write-down Type } \\
\text { (based on underlying exposure) }\end{array}$ & Benchmark Credit Index \\
Subprime Mortgage-backed Exposure & Markit ABX Index (1) \\
Commercial Mortgage-backed Exposure & Markit CMBX Index (2) \\
Leveraged Financing & Markit LCDX Index (3) \\
Collateralized Debt Obligations (CDOs) & Markit TABX Index (4) \\
Alt-A Mortgage-backed Exposure & Bloomberg 60+ days Alt-A Delinquency Index (5) \\
Prime Mortgage-backed Exposure & Bloomberg 60+ days Prime Delinquency Index (6) \\
Home Equity Exposure & Markit ABX Index \\
Monoline Guarantees & $\begin{array}{l}\text { Average Credit Default Swap Spread of monoline } \\
\text { bond insurance companies - Ambac, MBIA, Radian, } \\
\text { XL Capital, and FGIC (7) }\end{array}$ \\
Structured Investment Vehicles (SIVs) & Barclays U.S. Asset-backed Securities Index (8) \\
Asset-Backed Securities - general & Barclays U.S. Asset-backed Securities Index \\
Auction-rate Securities & Barclays U.S. Asset-backed Securities Index \\
Unspecified Residential Mortgage Exposure & Average of credit indices (1), (5) and (6) \\
\hline \hline
\end{tabular}




\section{Appendix 2: Items Comprising the ISS Corporate Governance Quotient Index (CGQ)}

This table provides the list of items used by Institutional Shareholder Services (ISS) in creating the corporate governance quotient (CGQ) index.

\section{Board}

1. Board composition

2. Nominating committee composition

3. Compensation committee composition

4. Governance committee

5. Board structure

6. Board size

7. Changes in board size

8. Cumulative voting

9. Boards served on - CEO

10. Boards served on - Other than CEO

11. Former CEOs on the board

12. Chairman/CEO separation

13. Governance guidelines

14. Response to shareholder proposals

15. Board attendance

16. Board vacancies

17. Related-party transactions - CEO

18. Related-party transactions - Other than CEO

19. Majority Voting

20. ISS Recommendation of Withhold Votes

\section{Audit}

21. Audit committee

22. Audit fees

23. Auditor ratification

24. Financial experts

25. Financial Restatements

26. Options Backdating

\section{Charter/Bylaws}

27. Poison pill adoption

28. Poison pill - shareholder approval

29. Poison pill - TIDE provision

30. Poison pill - sunset provision

31. Poison pill - qualified offer clause

32. Poison pill - trigger

33. Vote requirements - charter/bylaw amendments

34. Vote requirements - mergers

35. Written consent

36. Special meetings

37. Bylaw amendments

38. Capital structure - dual class

39. Capital structure - blank check preferred

\section{State of Incorporation}

40. State of incorporation antitakeover provisions

41. Control share acquisition

42. Control share cash-out

43. Freeze-out

44. Fair price

45. Stakeholder law

46. State endorsement of poison pills

\section{Ownership}

47. Director stock ownership

48. Executive stock ownership guidelines

49. Director stock ownership guidelines

50. Officer and director stock ownership levels

51. Mandatory holding period for stock options

52. Mandatory holding period for restricted stock

\section{Executive and Director Compensation}

53. Cost of option plans

54. Option re-pricing permitted

55. Shareholder approval of option plans

56. Compensation committee interlocks

57. Director compensation

58. Option burn rate

59. Performance-based compensation

60. Option expensing

\section{Progressive Practices}

61. Board performance reviews

62. Individual director performance reviews

63. Meetings of outside directors

64. CEO succession plan

65. Board can hire outside advisors

66. Directors resign upon job changes

\section{Director Education}

67. Directors participating in director education programs 


\section{Appendix 3: Excess CEO Compensation and Exposure to Risky Assets}

This Appendix provides corroborative evidence on the relation between management incentives and the extent of exposure to risky assets. The evidence presented here complements Hong, Chen, and Scheinkman (2009), who find that residualized (or "excess") CEO compensation is correlated with risk-taking for a large sample of financial institutions. I use the total dollar amount of write-downs during 2007 and 2008 as a perfect foresight proxy for the exposure to risky assets. In other words, institutions which took large asset write-downs during the crisis are the ones that accumulated exposures to risky assets in the period leading up to the crisis. The empirical test of this prediction employs the following cross-sectional regression:

$\begin{aligned} W D_{i}= & \alpha+\beta_{1} E X_{-} C O M P_{i}+\beta_{2} I N D E X \_C G Q_{i}+\beta_{3} \log (T A)_{i}+\beta_{4} R I S K \_C O M M_{i}+ \\ & \beta_{5} C R O_{i}+\beta_{6} T Y P E_{i}+\varepsilon_{i}\end{aligned}$

Where,

$W D_{i} \quad=$ total write-downs scaled by total assets for each firm $i$. Write-downs are cumulated over 2007 and 2008, while total assets are measured as of fiscal year end 2006. WD is used as a proxy for the extent of exposure to risky assets.

EX_COMP $P_{i}=$ excess CEO compensation measure in 2006 (refer Chapter 4.2 for details).

$I N D E X \_C G Q_{i}=$ corporate governance quotient (CGQ) index from Institutional Shareholder Services.

$\log (T A)_{i} \quad=$ logarithm of total assets at 2006 fiscal year end

$R I S K_{-} C O M M_{i}=$ an indicator variable for the presence of a risk committee

$\mathrm{CRO}_{i} \quad=$ an indicator variable for the presence of a chief risk officer

TYPE $\quad=$ indicator variables for the type of institution (or the sub-industry to which the firm belonged), at the end of fiscal 2006 (bank holding company, insurance company, investment bank, GSE or other categories)

According to the incentive misalignment predictions, in Equation A1, the coefficient on excess compensation EX_COMP is expected to be positive, while the coefficients on the 
governance and risk management variables (INDEX_CGQ, RISK_COMM, and CRO), if they are effective, are expected to be negative. The governance and risk management variables are measured pre-crisis (at the end of 2006) to mitigate simultaneity / endogeneity concerns and to reflect the fact that a majority of the credit risk exposures were built up during the pre-crisis period.

The table below presents the results of estimating Equation (A1). Columns I and II present the results without and with the additional risk management control variables, respectively.

Table A1: Excess CEO Compensation and Total Write-downs during 2007 and 2008

\begin{tabular}{lcc}
\hline \hline & I. & II. \\
\hline$E X \_C O M P$ & $0.503^{*}$ & $0.502 *$ \\
& {$[0.297]$} & {$[0.292]$} \\
$I N D E X_{-} C G Q$ & $0.002^{*}$ & $0.001^{*}$ \\
& {$[0.001]$} & {$[0.001]$} \\
LOG $(T A)$ & $-0.021^{*}$ & $-0.027^{* *}$ \\
& {$[0.012]$} & {$[0.013]$} \\
RISK_COMM & & -0.058 \\
& & {$[0.062]$} \\
CRO & & 0.108 \\
& & {$[0.068]$} \\
Constant & & 0.007 \\
& -0.021 & {$[0.058]$} \\
Observations & {$[0.054]$} & 58 \\
Institution Type Indicators & 58 & YES \\
Adj. R-squared & YES & 0.25 \\
\hline \hline Robust standard errors are in brackets. Standard errors are bootstrapped & 0.25 &
\end{tabular}

Robust standard errors are in brackets. Standard errors are bootstrapped with 1,000 replications.

As expected, the coefficient on EX_COMP is positive and significant (at $>10 \%$ level using a two-tailed test) in both specifications, indicating that write-downs are larger in firms with greater excess CEO compensation. The coefficients on $C R O$ and $R I S K_{-} C O M M$ are insignificant, 
while the coefficient on INDEX_CGQ is significant but contrary to the expected direction. ${ }^{32}$ Taken together, the results in this table provide some corroborative evidence that incentive problems were, to some extent, related to the exposure to risky assets. The results also lend support to the arguments that the extant corporate governance and risk management mechanisms were ineffective in constraining exposure to risky assets before the crisis.

\footnotetext{
${ }^{32}$ The economic significance of $I N D E X \_C G Q$ in this regression is lower than that of $E X \_C O M P$. Specifically, as the value of INDEX_CGQ increases from the $25^{\text {th }}$ percentile to the $75^{\text {th }}$ percentile, the dependent variable, $W D$, increases by 0.024 , whereas when $E X \_C O M P$ increases from the $25^{\text {th }}$ percentile to the $75^{\text {th }}$ percentile, WD increases by 0.04 .
} 


\section{Appendix 4: Disclosure Index Based on the SSG Best Practices Recommendations}

This table provides a list of items used in creating the disclosure index. The list is based on the Senior Supervisors Group's best practices recommendations for disclosures of selected exposures. The procedure for calculating the index is outlined in Chapter 5.4.

\section{Special Purpose Entities - General}

1 Total exposure to the SPEs

2 Exposure by type of SPE (CDO, ABCP conduits, SIV, others)

3 Distinguish between consolidated and non-consolidated

4 Identify circumstances which might over SPE on balance sheet

5 Breakdown of assets by:

Collateral type

Credit rating

Location of ultimate borrowers

Average maturity of obligations

\section{Collateralized Debt Obligations}

1 Total exposure to CDOs

2 Breakdown according to internal methodology (example, super senior exposures to high grade, mezzanine and $\mathrm{CDO}^{2}$ )

3 Separate data (identification) of CDOs according to the underlying collateral (example: Subprime mortgage and others)

4 Data on the vintage of the underlying subprime mortgages

4 Exposure before and after hedging

5 If hedged, notional amounts guaranteed by each financial guarantor

6 Credit ratings of financial guarantors

\section{Other Subprime and Alt-A Exposures}

1 Exposure to subprime and alt-A mortgages not in CDOs:

Whole loans, RBMS, via derivatives or commitments

2 Before and after hedging

3 Credit ratings of the instruments

IV. Commercial Mortgage-Backed Securities

1 Exposure to CMBS

2 Before and after hedging

3 By industry and geographic area

V. Leveraged Finance

1 Funded exposure and unfunded commitments

2 Change in exposure from prior periods, including sales and write-downs

3 Distribution of exposure by industry

4 Distribution of exposure by geography 


\section{Appendix 5: Alternative Dependent Variable}

I measure the sensitivity of daily stock returns to percentage daily changes in the ABX index prices and the percentage daily changes in the OIS spread (spread between the 3-month Libor and the corresponding OIS rate). I use the average of all series across all tranches of the ABX. For each firm in the sample, I estimate the following equation on a rolling basis from (and including) the fourth quarter of 2006 up to quarter $\tau$ (quarter $\tau$ being the quarter under consideration for which we want to measure the ex ante risk exposure).

$R_{i t} \quad=\alpha+\beta R m_{t}+\gamma_{\tau-1} \Delta A B X_{t}+\varphi_{\tau-1} O I S_{t}+\varepsilon_{i}$

Where,

$R_{i t} \quad=$ the daily stock return for firm $i$.

$R m_{t} \quad=$ the daily return on the CRSP equally weighted market portfolio.

$\triangle A B X_{t} \quad=$ the percentage change in average daily price of the ABX.

OIS $\quad=$ the percentage daily change in OIS spread.

$\gamma_{\tau}$ is the sensitivity of stock price changes to changes in the $\mathrm{ABX}$ index prices up to quarter $\tau$, and is an ex ante measure of exposure to risky subprime-related assets. I call this estimated coefficient $A B X \_B E T A_{\tau}$. 


\section{Appendix 6: A Brief Review of Financial Reporting Issues during the Crisis}

While the underlying causes of the financial crisis are likely to be debated for many years to come, inadequate financial reporting transparency concerning subprime mortgage and structured credit positions is a likely contender among many other explanations (Ryan 2008, Gorton 2008). The problem of lack of transparency in financial institutions is, however, not new. In addition to a large literature in finance and accounting, the Basel Committee on Banking Supervision has specifically argued for better disclosures to enable "market discipline" (Basel II Capital Accord). Indeed, Morgan (2002) argues that banks are inherently more opaque than other firms due to the uniqueness of their asset composition. Morgan calls banks "black holes of the universe - hugely powerful and influential, but to some irreducible extent - unfathomable." Given the importance of asset quality for financial institutions in general, it is imperative that the risks associated with poor asset quality are disclosed and recognized in an adequate and timely manner.

In the context of the financial crisis, discussion about accounting transparency has centered around two primary aspects of financial reporting: relevant and timely disclosures concerning the exposure to risky assets, and timely loss recognition (or asset write-downs). Critics have called into question the efficacy of pre-crisis financial disclosures. For example, Schwarz (2008) argues that accounting disclosures have been insufficient during the crisis.

The debate has been much more intense on another aspect of transparency, which involves the actual accounting recognition of credit losses through fair value accounting (more specifically, mark-to-market accounting). Extant literature on the value relevance of fair value accounting information has extensively documented the usefulness of fair value measurements to investors. Landsman (2007) provides an excellent review of this literature. However, in light of 
the assertions of extreme illiquidity in the structured credit markets, critics have called into question the usefulness of fair value accounting. There has been significant press coverage on the effects of fair value accounting during this crisis, with forceful arguments being made in favor of and against adopting fair value accounting.

Critics of fair value accounting argue that the prices of external observables used as valuation inputs during the crisis reflected market fear and panic rather than fundamental credit losses, and that fair value accounting that relied on these market observables produced valuation estimates that were substantially negatively biased (e.g., Stanton and Wallace 2009, Fender and Scheicher 2008). Another criticism of fair value accounting from a financial stability perspective is that under distressed market conditions, the fair value accounting induces a downward spiral in asset prices and causes further write-downs (this phenomenon is referred to as "procyclicality"). The argument is as follows: fair value accounting requires marking down exposures to reflect depressed asset values, even in highly volatile and illiquid market conditions. Financial institutions, in an attempt to avoid violation of regulatory capital or private contractual requirements, resort to distress selling of their assets, which in turn causes further downward pressure on asset prices and generates further accounting write-downs, ultimately threatening the solvency of financial institutions. Observers that have criticized the role of fair value accounting in exacerbating the severity of the crisis include, among many others, the American Bankers Association (2008), Forbes (2009), and Whalen (2009).

Proponents of fair value accounting argue that it provides relevant and informative signals, and that criticism of fair value accounting during the crisis was similar to "shooting the messenger" (Turner 2008, Vernon 2008, Ball 2008). Regarding the negative consequences of fair 
value accounting, Laux and Leuz (2009b) find no systematic evidence to support the allegations that fair value accounting exacerbated the crisis through fire sales.

Laux and Leuz (2009a, 2009b) provide a comprehensive review of the opinions expressed on this matter during the crisis. Studies that discuss the economic implications of fair value accounting include Allen and Carletti (2008), and Plantin, Sapra, and Shin (2008). 


\section{Figure 1: Aggregate Write-downs: Accounting vs. Index-implied Schedules}

This figure plots the paths of the aggregate cumulative quarterly accounting write-downs (WD_Actual) vs. the aggregate cumulative quarterly index-implied write-downs (WD_Implied) during 2007 and 2008. The key inference from the figure is that for each cumulative quarter, the index-implied write-downs are greater than or equal to the actual accounting write-downs. The analysis assumes that the total amount of write-down during 2007 and 2008 under the two schedules is the same - the only difference between the two schedules is the quarterly distribution of the total write-down.

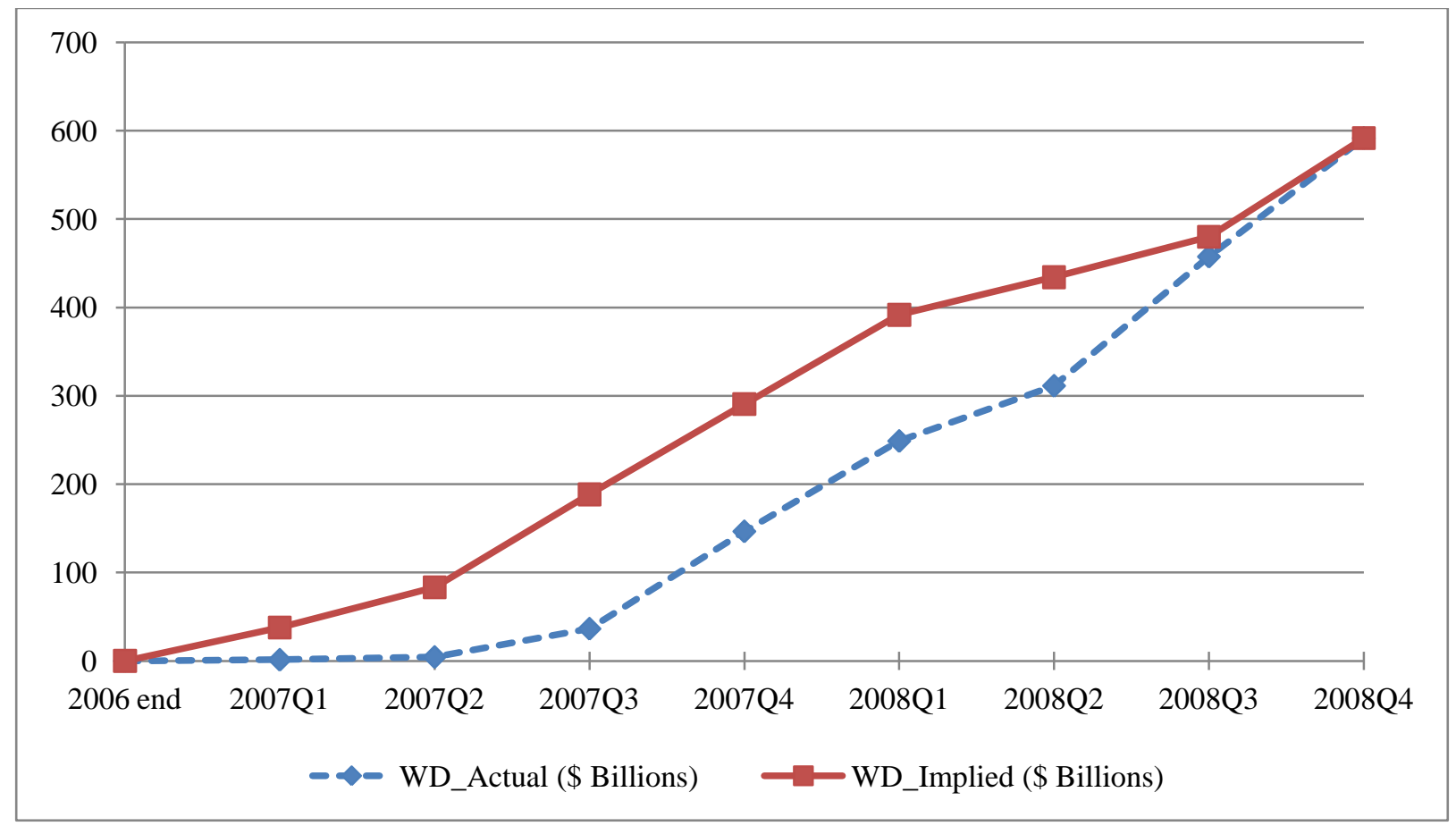




\section{Table 1: Data and Sample: Data Sources, Variable Definitions and Sample Constitution}

This table describes the data and variables used in this study. Panel A lists the data sources. Panel B describes the key variables used in this study. Panel C provides a breakdown of the sample by institution type.

\section{Panel A: Key Data Sources}

\begin{tabular}{|c|c|}
\hline Data Item & Source \\
\hline Credit Indices (listed in Appendix 1) & Reuters, Datastream, and Bloomberg. \\
\hline $\begin{array}{l}\text { Quarterly write-downs } \\
\text { (detailed in Chapter 3) }\end{array}$ & $\begin{array}{l}\text { Hand-collected data from annual and quarterly SEC filings, investor } \\
\text { presentations and earnings conference call transcripts. }\end{array}$ \\
\hline Regulatory investigation & $\begin{array}{l}\text { Firm disclosure of a sub-prime related SEC investigation (based on } \\
\text { media reports). }\end{array}$ \\
\hline Litigation exposure & $\begin{array}{l}\text { Credit crisis related securities class action lawsuits list obtained from } \\
\text { http://www.dandodiary.com/ and verified with the Stanford Securities } \\
\text { Class Action Clearinghouse database. }\end{array}$ \\
\hline Regulatory constraints & SNL Financial \\
\hline OIS spread & $\begin{array}{l}\text { Spread between the 3-month LIBOR ("London Interbank Offer Rate" } \\
\text { - the interest rate at which banks lend money to each other without } \\
\text { posting collateral) and the comparable overnight index swap rates } \\
\text { (OIS), i.e. the future expected policy rates (the Federal Funds rate in } \\
\text { the U.S.) over the same horizon. This is used as an important indicator } \\
\text { of general risk and liquidity in the money markets. Calculated with } \\
\text { data obtained from Bloomberg. }\end{array}$ \\
\hline Excess CEO compensation & $\begin{array}{l}\text { CEO compensation data are collected from Execucomp. The excess } \\
\text { component is calculated using the approach outlined in Chapter } 4 .\end{array}$ \\
\hline Corporate Governance & $\begin{array}{l}\text { "Corporate Governance Quotient" index scores distributed by } \\
\text { Institutional Shareholder Services (ISS) for 2006. Refer to Appendix } 2 .\end{array}$ \\
\hline Daily stock returns & CRSP \\
\hline $\begin{array}{l}\text { Financial statement variables such as } \\
\text { Total Assets, Total Liabilities and Book } \\
\text { Value }\end{array}$ & COMPUSTAT \\
\hline Disclosure Index & $\begin{array}{l}\text { A template created on the basis of Senior Supervisors Group's } \\
\text { recommendations for best practices in credit-crisis-related risk } \\
\text { disclosure. Data are collected from } 2006 \text { annual reports. }\end{array}$ \\
\hline
\end{tabular}




\section{Panel B: Variable Definitions}

\begin{tabular}{|c|c|}
\hline Variable Name & Description \\
\hline WD & $\begin{array}{l}\text { Total Write-downs during } 2007 \text { and } 2008 \text { divided by Total Assets. Write-downs refer to } \\
\text { net credit losses recognized through fair value adjustments, impairment charges, realized } \\
\text { losses on settlement of positions, and credit loss provisioning. }\end{array}$ \\
\hline$I P T \_W D$ & $\begin{array}{l}\text { Firm level measure of the timeliness of write-downs calculated using the procedure } \\
\text { outlined in Chapter } 4.1 \text {. }\end{array}$ \\
\hline$L O G(T A)$ & Logarithm of Total Assets at the end of fiscal 2006. \\
\hline$L E V$ & Total Liabilities divided by Total Assets at the end of fiscal 2006. \\
\hline$E X \_C O M P$ & Excess CEO compensation (see Chapter 4.2). \\
\hline $\begin{array}{l}A C L \_P N C \\
\left(A C L \_L I F E\right)\end{array}$ & $\begin{array}{l}\text { The Authorized Control Level Capital Ratio for Property and Casualty insurance (Life } \\
\text { insurance) companies. Firms that are not subject to regulation via this capital ratio are } \\
\text { assigned the maximum value of this ratio in the sample. }\end{array}$ \\
\hline TIERl & $\begin{array}{l}\text { The Tier I Capital Ratio for Bank Holding Companies. Firms that are not subject to } \\
\text { regulation via this capital ratio are assigned the maximum value of this ratio in the } \\
\text { sample. }\end{array}$ \\
\hline SUIT & $\begin{array}{l}\text { An indicator variable that takes on a value of one if the institution was subject to credit- } \\
\text { crisis related class action litigation prior to the quarter under consideration, zero } \\
\text { otherwise. }\end{array}$ \\
\hline$S E C$ & $\begin{array}{l}\text { An indicator variable that takes on a value of one if the institution is subject to a } \\
\text { subprime-related SEC investigation prior to the quarter under consideration,, zero } \\
\text { otherwise. }\end{array}$ \\
\hline OIS & $\begin{array}{l}\text { Cumulative quarterly percentage change in the OIS spread (defined as the spread } \\
\text { between the } 3 \text {-month LIBOR and the comparable overnight index swap rates (OIS), i.e. } \\
\text { future expected policy rates (the Federal Funds rate in the U.S. over the same horizon). } \\
\text { This is used as a proxy for general counterparty risk and liquidity factors in inter-bank } \\
\text { lending. }\end{array}$ \\
\hline COMPLEX & $\begin{array}{l}\text { Percentage of total write-downs attributable to Collateralized Debt Obligations (CDOs) } \\
\text { and Structured Investment Vehicles (SIVs). }\end{array}$ \\
\hline$I N D E X \_C G Q$ & Corporate Governance Quotient (CGQ) Index for 2006. \\
\hline$R I S K \_C O M M$ & $\begin{array}{l}\text { Indicator variable that takes on a value of one if the firm has a risk committee in } 2006 \text {, } \\
\text { zero otherwise. }\end{array}$ \\
\hline CRO & $\begin{array}{l}\text { Indicator variable that takes on a value of } 1 \text { if the firm has a chief risk officer (CRO) in } \\
2006 \text {, zero otherwise. }\end{array}$ \\
\hline DISCL2006 & Disclosure Score based on 2006 annual report disclosures (see Appendix 4). \\
\hline$A B X \_B E T A$ & $\begin{array}{l}\text { Sensitivity of stock returns to changes in the } \mathrm{ABX} \text { index, calculated using the procedure } \\
\text { outlined in Appendix } 5 \text {. }\end{array}$ \\
\hline
\end{tabular}




\section{Panel C: Sample Constitution by Type of Institution}

\begin{tabular}{lc} 
Institution type & Number of observations \\
\hline Bank Holding Companies & 21 \\
Investment Banks & 5 \\
Insurance companies & 39 \\
Others & 1 \\
Total & 66 \\
\hline
\end{tabular}




\section{Table 2: Descriptive Statistics and Pearson Correlations}

\section{Panel A: Descriptive Statistics}

This panel provides selected descriptive statistics for the 68 observations at the firm level. Variables are defined in Table 1, Panel B.

\begin{tabular}{lcccc}
\hline \hline & & & & \\
Variable & $\mathrm{N}$ & Mean & Median & Std. Dev. \\
\hline Total Write-down (\$ billions) & 66 & 8.82 & 1.72 & 18.00 \\
Timeliness of Write-downs (IPT_WD) & 523 & -0.12 & -0.10 & 0.22 \\
Log(Total Assets) & 66 & 4.12 & 4.04 & 1.72 \\
Leverage (LEV) & 66 & 0.83 & 0.89 & 0.15 \\
Complex & 66 & 0.11 & 0.00 & 0.18 \\
Litigation Exposure (SUIT) & 528 & 0.20 & 0.00 & 0.40 \\
SEC Investigation (SEC) & 528 & 0.06 & 0.00 & 0.23 \\
Risk Committee (RISK_COMM) & 66 & 0.45 & 0.00 & 0.50 \\
Chief Risk Officer (CRO) & 66 & 0.45 & 0.00 & 0.50 \\
Corporate Governance Index (INDEX_CGQ) & 58 & 82.00 & 87.95 & 19.79 \\
Excess Compensation (EX_COMP) & 58 & -0.01 & 0.00 & 0.08 \\
Disclosure Score (DISCL2006) & 68 & 0.27 & 0.33 & 0.17 \\
\hline \hline
\end{tabular}




\section{Panel B: Pearson Correlations}

This panel provides Pearson correlations between selected variables. Variables are defined in Table 1, Panel B.

\begin{tabular}{|c|c|c|c|c|c|c|c|c|c|c|c|c|c|}
\hline & $W D$ & $\log (T A)$ & $\begin{array}{l}E X_{-} \\
C O M P\end{array}$ & $\begin{array}{c}I N D E X \\
\_C G Q\end{array}$ & $C R O$ & $\begin{array}{l}\text { RISK}_{-} \\
\text {COMM }\end{array}$ & $L E V$ & $\begin{array}{l}\text { COMP- } \\
L E X\end{array}$ & $\begin{array}{l}\text { DISCL } \\
2006\end{array}$ & BHAR & $I P T_{-} W D$ & SEC & $S U I T$ \\
\hline$W D$ & 1 & & & & & & & & & & & & \\
\hline $\log (T A)$ & $0.6063^{*}$ & 1 & & & & & & & & & & & \\
\hline$E X \_C O M P$ & 0.1927 & 0.2115 & 1 & & & & & & & & & & \\
\hline$I N D E X \_C G Q$ & 0.1818 & $0.3029 *$ & 0.0916 & 1 & & & & & & & & & \\
\hline$C R O$ & $0.3829 *$ & $0.5042 *$ & 0.1382 & $0.3517^{*}$ & 1 & & & & & & & & \\
\hline$R I S K \_C O M M$ & 0.2359 & $0.4240^{*}$ & 0.1633 & $0.3573 *$ & $0.5722 *$ & 1 & & & & & & & \\
\hline$L E V$ & $0.2496 *$ & $0.6700 *$ & -0.066 & -0.0412 & $0.3498 *$ & $0.3191 *$ & 1 & & & & & & \\
\hline COMPLEX & $0.4351 *$ & $0.3225^{*}$ & 0.2356 & 0.1942 & $0.4456^{*}$ & 0.1701 & 0.0652 & 1 & & & & & \\
\hline DISCL2006 & $-0.3088 *$ & -0.2034 & -0.1847 & 0.0444 & -0.126 & 0.076 & -0.1105 & -0.1709 & 1 & & & & \\
\hline BHAR & $-0.1946^{*}$ & $-0.0896^{*}$ & $-0.1382 *$ & $-0.2973^{*}$ & $-0.2820 *$ & $-0.2635^{*}$ & 0.0205 & $-0.2376^{*}$ & $-0.1976^{*}$ & 1 & & & \\
\hline$I P T_{-} W D$ & -0.0604 & $-0.1095^{*}$ & -0.0363 & $0.1520 *$ & 0.0295 & 0.0402 & $-0.2252 *$ & -0.0456 & $0.1404 *$ & $-0.2018 *$ & 1 & & \\
\hline$S E C$ & $0.2545^{*}$ & $0.2878 *$ & 0.0579 & $0.1472 *$ & $0.2070^{*}$ & $0.1408 *$ & $0.1667 *$ & $0.1920 *$ & -0.0319 & $-0.3032 *$ & $0.1114^{*}$ & 1 & \\
\hline SUIT & $0.4102 *$ & $0.1642 *$ & $0.0990^{*}$ & $0.2862 *$ & $0.3256^{*}$ & $0.2850 *$ & -0.0369 & $0.3060 *$ & 0.0826 & $-0.5688^{*}$ & $0.1520 *$ & $0.4507^{*}$ & 1 \\
\hline
\end{tabular}

* denotes significance at the $>0.05$ percent level 


\section{Table 3: On-average Timeliness of Write-downs}

This table presents $t$-tests of differences in means between the cumulative quarterly accounting write-downs and the index-implied write-downs.

\begin{tabular}{lcccc}
\hline \hline Quarter & $\begin{array}{c}\text { Cumulative Accounting } \\
\text { Write-downs } \\
\text { (mean) }\end{array}$ & $\begin{array}{c}\text { Cumulative Index-implied } \\
\text { Write-downs } \\
\text { (mean) }\end{array}$ & $\begin{array}{c}\text { Difference } \\
\text { in means (A-B) }\end{array}$ & t-stat \\
\hline 2007 Q1 & 0.02 & 0.53 & -0.51 & -3.69 \\
2007 Q2 & 0.06 & 1.17 & -1.11 & -3.50 \\
2007 Q3 & 0.51 & 2.65 & -2.14 & -3.42 \\
2007 Q4 & 2.07 & 4.09 & -2.03 & -3.71 \\
2008 Q1 & 3.51 & 5.52 & -2.01 & -3.92 \\
2008 Q2 & 4.39 & 6.12 & -1.73 & -3.95 \\
2008 Q3 & 6.44 & 6.76 & -0.32 & -1.33 \\
2008 Q4 & 8.33 & 8.33 & 0.00 & - \\
& & & \\
\hline \hline
\end{tabular}




\section{Table 4: Cross-sectional Determinants of the Timeliness of Write-downs}

This table presents a multivariate analysis of the factors related to the timeliness of write-downs. Columns I to V present the results of sequentially introducing the explanatory variables in the regressions. Standard errors (in brackets) are clustered at the firm level and at the quarter level. ***,** and $*$ denote significance at the $1 \%, 5 \%$ and 10\% levels, respectively, using two-tailed tests. Variables are defined in Table 1, Panel B.

$I P T_{-} W D_{i, \tau}=\alpha+\beta_{1} W D_{i}+\beta_{2} L E V_{i}+\beta_{3} A C L_{-} P N C_{i}+\beta_{4} A C L_{-} L I F E_{i}+\beta_{5} T I E R 1_{i}+\beta_{6} \log (T A)_{i}+$

$$
\beta_{7} \text { COMPLEX }_{i}+\beta_{8} E X_{-} C O M P_{i}+\beta_{9} I N D E X_{-} C G Q_{i}+\beta_{10} S E C_{i, \tau}+\beta_{1 I} S U I T_{i, \tau}+\gamma T_{y p e_{i}}+\varepsilon_{i}
$$

\begin{tabular}{|c|c|c|c|c|c|}
\hline & I. & II. & III. & IV. & V. \\
\hline \multirow[t]{2}{*}{$W D$} & -0.001 & -0.036 & -0.012 & -0.051 & -0.012 \\
\hline & {$[0.071]$} & {$[0.073]$} & {$[0.076]$} & {$[0.066]$} & [0.067] \\
\hline \multirow[t]{2}{*}{$\log (T A)$} & $0.024 * *$ & 0.015 & 0.011 & 0.009 & 0.01 \\
\hline & [0.011] & {$[0.011]$} & {$[0.010]$} & {$[0.010]$} & [0.009] \\
\hline \multirow[t]{2}{*}{$L E V$} & $-0.479 * *$ & $-0.401 * *$ & $-0.393 * *$ & $-0.365^{*}$ & $-0.476 * *$ \\
\hline & [0.206] & [0.194] & [0.193] & {$[0.188]$} & [0.201] \\
\hline \multirow[t]{2}{*}{$A C L \_P N C$} & $0.001 * * *$ & $0.001 * * *$ & $0.001 * * *$ & $0.001 * * *$ & $0.001 * * *$ \\
\hline & {$[0.000]$} & {$[0.000]$} & {$[0.000]$} & {$[0.000]$} & {$[0.000]$} \\
\hline \multirow[t]{2}{*}{$A C L \_L I F E$} & 0.001 & 0.001 & 0.001 & 0.001 & 0.001 \\
\hline & {$[0.001]$} & {$[0.001]$} & {$[0.001]$} & {$[0.001]$} & {$[0.001]$} \\
\hline \multirow[t]{2}{*}{ TIERI } & $0.023 * *$ & $0.025^{* *}$ & 0.021 & 0.02 & 0.056 \\
\hline & {$[0.011]$} & {$[0.012]$} & {$[0.013]$} & {$[0.013]$} & {$[0.038]$} \\
\hline \multirow[t]{2}{*}{ COMPLEX } & $-0.146^{* * *}$ & $-0.134 * * *$ & $-0.149 * * *$ & $-0.156 * * *$ & $-0.144 * * *$ \\
\hline & {$[0.051]$} & [0.047] & {$[0.051]$} & {$[0.052]$} & {$[0.055]$} \\
\hline \multirow[t]{2}{*}{$E X \_C O M P$} & -0.141 & -0.111 & -0.113 & -0.097 & -0.089 \\
\hline & [0.198] & [0.203] & {$[0.203]$} & [0.203] & [0.201] \\
\hline \multirow[t]{2}{*}{ INDEX_CGQ } & & $0.001 * *$ & $0.001 * *$ & 0.001** & $0.001 * *$ \\
\hline & & {$[0.000]$} & {$[0.000]$} & {$[0.000]$} & {$[0.000]$} \\
\hline \multirow[t]{2}{*}{$S E C$} & & & $0.074 * *$ & 0.04 & 0.054 \\
\hline & & & {$[0.032]$} & [0.029] & {$[0.030]$} \\
\hline \multirow[t]{2}{*}{ SUIT } & & & & $0.056 * * *$ & $0.040^{*}$ \\
\hline & & & & [0.013] & {$[0.023]$} \\
\hline Institution Type Indicators & NO & NO & NO & NO & YES \\
\hline \multirow[t]{2}{*}{ Constant } & -0.165 & -0.298 & -0.233 & -0.231 & -0.361 \\
\hline & [0.179] & {$[0.203]$} & {$[0.231]$} & {$[0.226]$} & {$[0.327]$} \\
\hline Observations & 461 & 461 & 461 & 461 & 461 \\
\hline Adj. R-squared & 0.08 & 0.088 & 0.092 & 0.098 & 0.112 \\
\hline
\end{tabular}




\section{Table 5: Timeliness of Stock Market Adjustment}

This panel presents the results of cumulative quarterly and pooled regressions of buy-and-hold abnormal returns (from beginning of 2007 to the end of quarter $\tau$ ) on total write-downs during 2007 and 2008 (scaled by total assets), timeliness of write-downs and the interaction between them. The key variable of interest is the interaction between $W D$ and $I P T_{-} W D$. A negative coefficient on the interaction term implies that credit losses are incorporated into stock returns on a timelier basis for firms with timelier write-downs. Standard errors in the cumulative quarterly regressions are heteroskedasticity-robust. In the pooled regression, the standard errors are clustered at the firm level and at the quarter level. Standard errors are in brackets. ***, ** and * denote significance at the $1 \%, 5 \%$ and $10 \%$ levels, respectively, using two-tailed tests. Variables are defined in Table 1, Panel B.

BHAR $_{i, \tau}=\alpha+\beta_{1} W D_{i}+\beta_{2} I P T_{-} W D_{i, \tau}+\beta_{3} W D_{i} \times I P T_{-} W D_{i, \tau}+\beta_{4} O I S_{\tau}+\beta_{5} \log (T A)_{i}+\beta_{6} I N D E X_{-} C G Q_{i}+\varepsilon_{i, \tau}$

\begin{tabular}{|c|c|c|c|c|c|c|c|c|}
\hline & \multicolumn{8}{|c|}{ OLS Regressions } \\
\hline & 2007 Q1 & $2007 \mathrm{Q} 2$ & 2007 Q3 & 2007 Q4 & 2008 Q1 & $2008 \mathrm{Q} 2$ & $2008 \mathrm{Q} 3$ & Pooled \\
\hline \multirow[t]{2}{*}{$W D$} & $-0.739 * * *$ & $-0.932 *$ & $-1.514 * * *$ & $-1.669 * * *$ & $-1.341 * * *$ & $-0.959 * * *$ & $-1.395 * * *$ & $-1.142 * * *$ \\
\hline & {$[0.257]$} & {$[0.522]$} & {$[0.277]$} & {$[0.397]$} & {$[0.255]$} & [0.329] & {$[0.266]$} & [0.269] \\
\hline \multirow[t]{2}{*}{$I P T_{-} W D$} & -0.058 & 0.266 & 0 & $-0.257 * *$ & $-0.338 * *$ & $-0.474 * * *$ & 0.277 & -0.166 \\
\hline & {$[0.095]$} & {$[0.259]$} & {$[0.118]$} & {$[0.126]$} & {$[0.141]$} & {$[0.174]$} & {$[0.370]$} & {$[0.110]$} \\
\hline \multirow[t]{2}{*}{$W D * I P T_{-} W D$} & $\mathbf{- 8 . 5 3 0} * * *$ & $-4.504 *$ & $-3.153 * * *$ & $-3.447 * *$ & $-2.001 *$ & 0.712 & $-9.987 *$ & $-2.570 * * *$ \\
\hline & {$[2.936]$} & {$[2.623]$} & {$[0.712]$} & {$[1.690]$} & {$[1.165]$} & [2.059] & {$[5.178]$} & {$[0.846]$} \\
\hline \multirow[t]{2}{*}{ OIS } & & & & & & & & $-0.021 * * *$ \\
\hline & & & & & & & & {$[0.004]$} \\
\hline \multirow[t]{2}{*}{$\log (T A)$} & -0.001 & -0.006 & -0.002 & -0.019 & $-0.024 *$ & $-0.028 *$ & -0.037 & $-0.025^{* *}$ \\
\hline & {$[0.005]$} & {$[0.005]$} & {$[0.008]$} & {$[0.012]$} & {$[0.013]$} & {$[0.015]$} & {$[0.023]$} & {$[0.011]$} \\
\hline \multirow[t]{2}{*}{ Index_CGQ } & 0.001 & -0.001 & $-0.001 * *$ & 0.001 & -0.001 & -0.002 & $-0.005^{*}$ & $-0.002 *$ \\
\hline & {$[0.001]$} & {$[0.001]$} & {$[0.001]$} & {$[0.001]$} & {$[0.001]$} & {$[0.002]$} & {$[0.002]$} & {$[0.001]$} \\
\hline \multirow[t]{2}{*}{ Constant } & 0.006 & 0.041 & $-0.088 * *$ & $-0.126 * *$ & $-0.130^{*}$ & $-0.283 * * *$ & -0.035 & $0.121 * *$ \\
\hline & {$[0.026]$} & {$[0.038]$} & {$[0.038]$} & {$[0.059]$} & {$[0.065]$} & {$[0.080]$} & {$[0.105]$} & {$[0.055]$} \\
\hline Industry Type Indicators & Yes & Yes & Yes & Yes & Yes & Yes & Yes & Yes \\
\hline Observations & 66 & 66 & 66 & 66 & 66 & 66 & 64 & 460 \\
\hline Adj. R-squared & 0.15 & 0.27 & 0.58 & 0.65 & 0.58 & 0.51 & 0.28 & 0.41 \\
\hline
\end{tabular}




\section{Table 5 Panel B: Timeliness of Stock Market Adjustment: Instrumental Variables Regressions}

This panel presents the instrumental variables regression analysis of the impact of timeliness of write-downs on the relation between buy-and-hold abnormal returns and total write-downs during 2007 and 2008. The key variable of interest in the second stage is the interaction between the predicted values of $W D$ and $I P T_{-} W D$. A negative coefficient on the interaction term implies that credit losses are incorporated into stock returns on a timelier basis for firms with timelier write-downs. Standard errors are heteroskedasticity-robust. Standard errors are in brackets. ***, ** and * denote significance at the $1 \%, 5 \%$ and $10 \%$ levels, respectively, using two-tailed tests. Variables are defined in Table 1, Panel B.

BHAR $_{i, \tau} \quad=\quad \alpha+\beta_{1} W D_{i}+\beta_{2} I P T_{-} W D_{i, \tau}+\beta_{3} W D_{i} \times I P T_{-} W D_{i, \tau}+\beta_{4} O I S_{\tau}+\beta_{5} \log (T A)_{i}+\beta_{6} I N D E X_{-} C G Q_{i}+\varepsilon_{i, \tau}$

\begin{tabular}{|c|c|c|c|c|c|c|c|c|}
\hline & \multicolumn{8}{|c|}{ Instrumental Variables Regressions } \\
\hline & 2007 Q1 & 2007 Q2 & $2007 \mathrm{Q} 3$ & $2007 \mathrm{Q} 4$ & 2008 Q1 & $2008 \mathrm{Q} 2$ & $2008 \mathrm{Q} 3$ & Pooled \\
\hline \multirow[t]{2}{*}{$W D$} & 0.100 & -0.848 & $-0.904 *$ & -0.872 & $-1.095 * * *$ & -0.602 & $-2.120 * * *$ & $-2.065 * * *$ \\
\hline & [0.349] & {$[0.570]$} & {$[0.536]$} & {$[0.835]$} & {$[0.345]$} & [0.393] & {$[0.646]$} & {$[0.672]$} \\
\hline \multirow[t]{2}{*}{$I P T_{-} W D$} & -0.294 & $0.950 * *$ & 0.201 & -0.401 & $-0.459 * *$ & $-1.101 * * *$ & 0.093 & $-0.617 * *$ \\
\hline & {$[0.227]$} & {$[0.415]$} & {$[0.257]$} & {$[0.257]$} & {$[0.213]$} & [0.190] & {$[0.628]$} & {$[0.251]$} \\
\hline \multirow[t]{2}{*}{$W D * I P T_{-} W D$} & 1.233 & $-5.844 *$ & -2.337 & -0.788 & -3.03 & 0.721 & $-27.846 * *$ & $-12.431 * *$ \\
\hline & [4.344] & [3.379] & [1.771] & [4.379] & [2.574] & [3.120] & [11.978] & [4.978] \\
\hline \multirow[t]{2}{*}{ OIS } & & & & & & & & $-0.029 * * *$ \\
\hline & & & & & & & & {$[0.002]$} \\
\hline \multirow[t]{2}{*}{$\log (T A)$} & 0.001 & 0.010 & $0.017^{*}$ & 0.003 & -0.002 & -0.01 & $-0.083 * * *$ & $-0.021 *$ \\
\hline & {$[0.004]$} & {$[0.007]$} & [0.009] & {$[0.018]$} & [0.016] & {$[0.021]$} & {$[0.025]$} & {$[0.012]$} \\
\hline \multirow[t]{2}{*}{ Index_CGQ } & 0.001 & $-0.002 * * *$ & $-0.003 * * *$ & -0.002 & -0.002 & $-0.003^{*}$ & -0.001 & 0.001 \\
\hline & {$[0.000]$} & [0.000] & [0.001] & {$[0.002]$} & [0.002] & [0.002] & [0.002] & {$[0.001]$} \\
\hline \multirow[t]{2}{*}{ Constant } & 0.048 & 0.102 & -0.015 & 0.236 & 0.278 & 0.295 & 0.278 & $0.381 * * *$ \\
\hline & [0.059] & {$[0.081]$} & [0.118] & {$[0.212]$} & {$[0.235]$} & [0.282] & [0.337] & {$[0.088]$} \\
\hline Observations & 58 & 58 & 58 & 58 & 58 & 58 & 58 & 406 \\
\hline Adj. R-squared & 0.18 & 0.15 & 0.27 & 0.23 & 0.3 & 0.14 & 0.24 & 0.29 \\
\hline
\end{tabular}




\section{Table 6: Timeliness of Stock Market Adjustment: 2006 Annual Report Disclosures as an Ex Ante Transparency Measure}

This panel presents the results of the cumulative quarterly and pooled regressions of buy-and-hold abnormal returns (from beginning of 2007 to the end of quarter $\tau$ ) on total asset write-downs during 2007 and 2008 scaled by total assets, disclosure scores and the interaction between them. The key variable of interest is the interaction between total write-downs and disclosure scores. A negative coefficient on the interaction term implies that credit losses are incorporated into stock returns on a timelier basis for firms with higher disclosure scores. Standard errors in the cumulative quarterly regressions are heteroskedasticity-robust. In the pooled regressions, the standard errors are clustered at the firm and quarter levels. Standard errors are in brackets. ***, ** and * denote significance at the $1 \%, 5 \%$ and $10 \%$ levels, respectively, using two-tailed tests. Variables are defined in Table 1, Panel B.

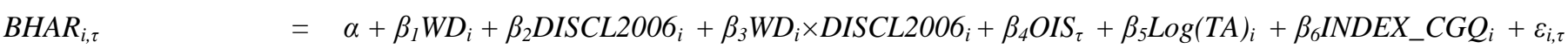

\begin{tabular}{|c|c|c|c|c|c|c|c|c|c|}
\hline & 2007 Q1 & 2007 Q2 & $2007 \mathrm{Q} 3$ & 2007 Q4 & $2008 \mathrm{Q} 1$ & $2008 \mathrm{Q} 2$ & $2008 \mathrm{Q} 3$ & $2008 \mathrm{Q} 4$ & Pooled \\
\hline \multirow[t]{2}{*}{$W D$} & -0.058 & -0.084 & -0.086 & $-0.462 * *$ & $-0.703 * * *$ & $-0.642 * * *$ & $-0.772 * *$ & $-0.580 *$ & $-0.423 * * *$ \\
\hline & {$[0.064]$} & {$[0.088]$} & {$[0.133]$} & [0.199] & {$[0.219]$} & {$[0.220]$} & {$[0.350]$} & {$[0.290]$} & {$[0.081]$} \\
\hline \multirow[t]{2}{*}{ DISCL2006 } & 0.012 & 0.003 & 0.02 & -0.08 & -0.199 & -0.172 & -0.204 & -0.319 & -0.117 \\
\hline & {$[0.073]$} & {$[0.081]$} & {$[0.111]$} & {$[0.193]$} & {$[0.219]$} & {$[0.247]$} & {$[0.379]$} & {$[0.398]$} & {$[0.156]$} \\
\hline \multirow[t]{2}{*}{$W D * D I S C L 2006$} & -0.057 & -0.284 & $-2.271 * * *$ & $-3.604 * * *$ & $-3.514 * * *$ & $-3.662 * * *$ & $-3.323^{*}$ & $-4.613 * *$ & $-2.667 * * *$ \\
\hline & {$[0.509]$} & {$[0.511]$} & {$[0.694]$} & [1.121] & [1.267] & {$[1.282]$} & {$[1.868]$} & {$[2.028]$} & {$[0.765]$} \\
\hline \multirow[t]{2}{*}{ OIS } & & & & & & & & & $-0.021 * * *$ \\
\hline & & & & & & & & & {$[0.003]$} \\
\hline \multirow[t]{2}{*}{$\log (T A)$} & 0.003 & 0.011 & $0.035^{* * *}$ & 0.027 & 0.02 & 0.019 & 0.009 & -0.045 & 0.01 \\
\hline & {$[0.007]$} & {$[0.008]$} & {$[0.012]$} & {$[0.017]$} & {$[0.022]$} & {$[0.025]$} & {$[0.039]$} & {$[0.043]$} & {$[0.018]$} \\
\hline \multirow[t]{2}{*}{ Index_CGQ } & 0.001 & 0.001 & $-0.002 *$ & -0.002 & $-0.003 *$ & -0.002 & $-0.004 *$ & $-0.005 *$ & $-0.002 * *$ \\
\hline & {$[0.001]$} & {$[0.001]$} & {$[0.001]$} & {$[0.001]$} & {$[0.002]$} & {$[0.002]$} & {$[0.002]$} & {$[0.003]$} & {$[0.001]$} \\
\hline \multirow[t]{2}{*}{ Constant } & -0.017 & -0.036 & -0.102 & -0.032 & 0.12 & -0.016 & 0.263 & $0.527 * *$ & 0.084 \\
\hline & {$[0.041]$} & {$[0.054]$} & {$[0.072]$} & {$[0.102]$} & {$[0.116]$} & {$[0.129]$} & {$[0.186]$} & {$[0.223]$} & {$[0.137]$} \\
\hline Industry Type Indicators & Yes & Yes & Yes & Yes & Yes & Yes & Yes & Yes & Yes \\
\hline Observations & 58 & 58 & 58 & 58 & 58 & 58 & 58 & 56 & 462 \\
\hline Adj. R-squared & 0.09 & 0.21 & 0.5 & 0.51 & 0.49 & 0.47 & 0.26 & 0.3 & 0.39 \\
\hline
\end{tabular}




\section{Table 7: Timeliness of Stock Market Adjustment: Using a Market-based Measure of Exposure to Risky Assets}

This panel presents the results of cumulative quarterly and pooled regressions of $A B X \_B E T A$ (a market-based measure of exposure to risky assets) from beginning of 2007 to the end of quarter $\tau$ on total write-downs during 2007 and 2008 (scaled by total assets), timeliness of write-downs and the interaction between them. The key variable of interest is the interaction between $W D$ and $I P T_{-} W D$. A positive coefficient on the interaction term implies that credit losses are incorporated into $A B X \_B E T A$ on a timelier basis for firms with timelier write-downs. Standard errors in the cumulative quarterly regressions are heteroskedasticity-robust. In the pooled regression, the standard errors are clustered at the firm level and at the quarter level. Standard errors are in brackets. ***, ** and * denote significance at the $1 \%, 5 \%$ and $10 \%$ levels, respectively, using two-tailed tests. Variables are defined in Table 1 , Panel B.

$A B X \_B E T A_{i, \tau} \quad=\alpha+\beta_{1} W D_{i}+\beta_{2} I P T_{-} W D_{i, \tau}+\beta_{3} W D_{i} \times I P T_{-} W D_{i, \tau}+\beta_{4} O I S_{\tau}+\beta_{5} \log (T A)_{i}+\beta_{6} I N D E X_{-} C G Q_{i}+\varepsilon_{i, \tau}$

\begin{tabular}{|c|c|c|c|c|c|c|c|}
\hline & $2007 \mathrm{Q} 2$ & 2007 Q3 & $2007 \mathrm{Q} 4$ & 2008 Q1 & $2008 \mathrm{Q} 2$ & $2008 \mathrm{Q} 3$ & Pooled \\
\hline \multirow[t]{2}{*}{$W D$} & -1.03 & $0.772^{*}$ & $0.852 * * *$ & $0.664 * * *$ & $0.806^{* * *}$ & $0.424 * * *$ & $0.628 * * *$ \\
\hline & [1.582] & [0.439] & {$[0.258]$} & {$[0.157]$} & {$[0.156]$} & [0.095] & {$[0.105]$} \\
\hline \multirow[t]{2}{*}{$I P T_{-} W D$} & -0.269 & -0.132 & 0.025 & -0.021 & 0.032 & $-0.126 * *$ & -0.004 \\
\hline & [0.244] & [0.144] & [0.106] & {$[0.085]$} & [0.064] & {$[0.053]$} & {$[0.038]$} \\
\hline \multirow[t]{2}{*}{$W D^{*} I P T_{-} W D$} & -5.608 & 1.605 & $2.213 * *$ & $1.305 *$ & 1.132 & $3.354 * * *$ & $1.449 * * *$ \\
\hline & [7.811] & [1.053] & [1.046] & {$[0.718]$} & {$[0.974]$} & [1.087] & {$[0.428]$} \\
\hline \multirow[t]{2}{*}{ OIS } & & & & & & & 0.002 \\
\hline & & & & & & & [0.001] \\
\hline \multirow[t]{2}{*}{$\log (T A)$} & $0.079 * * *$ & $0.040 * *$ & 0.007 & -0.004 & -0.014 & -0.003 & 0.019 \\
\hline & {$[0.023]$} & {$[0.016]$} & {$[0.011]$} & [0.009] & {$[0.009]$} & {$[0.007]$} & [0.017] \\
\hline \multirow[t]{2}{*}{$I N D E X \_C G Q$} & 0.001 & $0.002 *$ & 0.001 & $0.002 * * *$ & $0.003 * * *$ & $0.001 * * *$ & $0.002 * * *$ \\
\hline & [0.002] & {$[0.001]$} & {$[0.001]$} & {$[0.001]$} & {$[0.001]$} & {$[0.001]$} & {$[0.001]$} \\
\hline \multirow[t]{2}{*}{ Constant } & $-0.357 * *$ & $-0.268 * * *$ & $-0.157 * *$ & $-0.150 * *$ & $-0.139 * *$ & $-0.078 * *$ & $-0.224 * *$ \\
\hline & [0.154] & [0.100] & {$[0.075]$} & [0.059] & {$[0.061]$} & {$[0.036]$} & [0.103] \\
\hline Institution Type Indicators & Yes & Yes & Yes & Yes & Yes & Yes & Yes \\
\hline Observations & 58 & 58 & 58 & 58 & 58 & 58 & 348 \\
\hline Adj. R-squared & 0.25 & 0.24 & 0.32 & 0.45 & 0.52 & 0.39 & 0.24 \\
\hline
\end{tabular}


Table 8: Cross Sectional Determinants of Timelines of Write-downs: Additional Controls

Panel A: Additional Controls for Exposure-Specificity

This table presents a multivariate analysis of the factors related to the timeliness of write-downs with additional control variables. Panel A presents the results with additional controls for exposure-specificity. Column I presents the results with the additional control variables included individually, while Column II presents the results using the first principal component of the additional control variables. Both Columns include industry fixed effects. Standard errors (in brackets) are clustered at the firm level and at the quarter level. $* * *, * *$ and $*$ denote significance at the $1 \%, 5 \%$ and $10 \%$ levels, respectively, using two-tailed tests. The additional control variables are defined in Chapter 5.4. Other variables are defined in Table 1, Panel B.

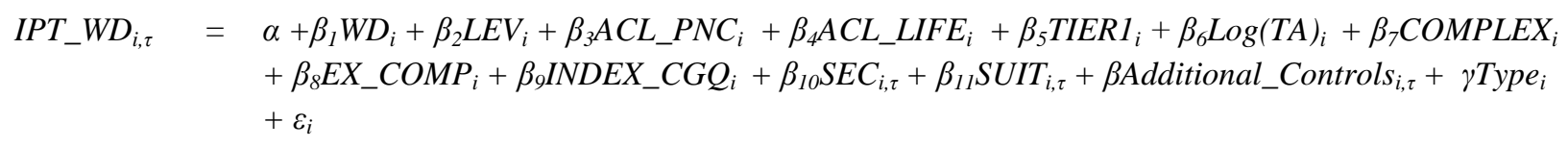

\begin{tabular}{|c|c|c|}
\hline & I. & II. \\
\hline \multirow[t]{2}{*}{$W D$} & -0.023 & -0.043 \\
\hline & {$[0.105]$} & {$[0.082]$} \\
\hline \multirow[t]{2}{*}{$\log (T A)$} & 0.004 & 0.009 \\
\hline & {$[0.010]$} & [0.009] \\
\hline \multirow[t]{2}{*}{$L E V$} & $-0.383 * *$ & $-0.404 * *$ \\
\hline & [0.188] & {$[0.186]$} \\
\hline \multirow[t]{2}{*}{$A C L \_P N C$} & $0.001 *$ & $0.001 * *$ \\
\hline & {$[0.000]$} & {$[0.000]$} \\
\hline \multirow[t]{2}{*}{$A C L \_L I F E$} & 0.001 & 0.001 \\
\hline & {$[0.001]$} & [0.001] \\
\hline \multirow[t]{2}{*}{ TIERI } & $0.063^{*}$ & $0.066^{*}$ \\
\hline & {$[0.034]$} & [0.037] \\
\hline \multirow[t]{2}{*}{ COMPLEX } & -0.07 & $-0.111^{*}$ \\
\hline & {$[0.065]$} & {$[0.063]$} \\
\hline \multirow[t]{2}{*}{$E X \_C O M P$} & -0.064 & -0.012 \\
\hline & [0.215] & {$[0.213]$} \\
\hline \multirow[t]{2}{*}{ INDEX_CGQ } & $0.001 * *$ & $0.001 * *$ \\
\hline & {$[0.000]$} & {$[0.000]$} \\
\hline \multirow[t]{2}{*}{$S E C$} & 0.054 & 0.074 \\
\hline & {$[0.05]$} & {$[0.05]$} \\
\hline \multirow[t]{2}{*}{ SUIT } & $0.042 * *$ & $0.049 * *$ \\
\hline & {$[0.019]$} & [0.019] \\
\hline \multirow[t]{2}{*}{ GEOGRAPHY } & $-0.269 * *$ & \\
\hline & [0.104] & \\
\hline \multirow[t]{2}{*}{ SINGLE_FAMILY } & -0.015 & \\
\hline & [0.064] & \\
\hline \multirow[t]{2}{*}{ RATED_A+ } & -0.036 & \\
\hline & [0.048] & \\
\hline
\end{tabular}


CDO_HG

CDO_SQ

LESS_RISKY

Constant

Observations

Adj. R-squared
$-0.146^{*}$

[0.085]

$-0.008$

[0.122]

$-0.325$

[0.312]

453

0.131
$-0.035^{* * *}$

[0.014]

$-0.659$

[0.431]

453

0.135 


\section{Table 8 Panel B: Cross Sectional Determinants of Timelines of Write-downs: Additional Control for Monoline Hedges}

This table presents a multivariate analysis of the factors related to the timeliness of write-downs, including additional control variables. Panel B includes additional controls for exposure-specificity and monoline hedges. Standard errors (in brackets) are clustered at the firm level and at the quarter level. ***,** and $*$ denote significance at the $1 \%, 5 \%$ and $10 \%$ levels, respectively, using two-tailed tests. The additional control variables are defined in Chapter 5.4. Other variables are defined in Table 1, Panel B.

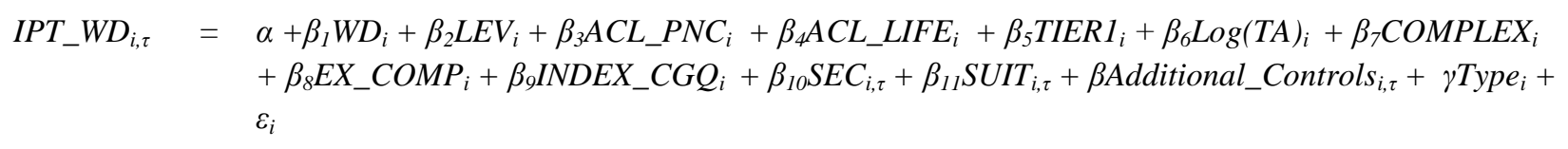

\begin{tabular}{|c|c|}
\hline & I. \\
\hline \multirow[t]{2}{*}{$W D$} & -0.061 \\
\hline & {$[0.087]$} \\
\hline \multirow[t]{2}{*}{$\log (T A)$} & 0.01 \\
\hline & {$[0.009]$} \\
\hline \multirow[t]{2}{*}{$L E V$} & $-0.403^{* *}$ \\
\hline & [0.189] \\
\hline \multirow[t]{2}{*}{$A C L \_P N C$} & $0.001 * *$ \\
\hline & {$[0.000]$} \\
\hline \multirow[t]{2}{*}{$A C L \_L I F E$} & 0.001 \\
\hline & {$[0.001]$} \\
\hline \multirow[t]{2}{*}{ TIER1 } & $0.066^{*}$ \\
\hline & {$[0.037]$} \\
\hline \multirow[t]{2}{*}{ COMPLEX } & -0.084 \\
\hline & {$[0.064]$} \\
\hline \multirow[t]{2}{*}{ EX_COMP } & -0.046 \\
\hline & {$[0.223]$} \\
\hline \multirow[t]{2}{*}{ INDEX_CGQ } & $0.001 *$ \\
\hline & {$[0.001]$} \\
\hline \multirow[t]{2}{*}{$S E C$} & 0.074 \\
\hline & {$[0.05]$} \\
\hline \multirow[t]{2}{*}{ SUIT } & $0.049 * *$ \\
\hline & {$[0.019]$} \\
\hline \multirow[t]{2}{*}{ LESS_RISKY } & $-0.036 * * *$ \\
\hline & {$[0.014]$} \\
\hline \multirow[t]{2}{*}{ MONOLINE } & $-0.459^{*}$ \\
\hline & {$[0.238]$} \\
\hline Institution Type Indicators & YES \\
\hline \multirow[t]{2}{*}{ Constant } & -0.659 \\
\hline & {$[0.431]$} \\
\hline Observations & 453 \\
\hline Adj. R-squared & 0.135 \\
\hline
\end{tabular}




\section{Table 8 Panel C: Cross Sectional Determinants of Timelines of Write-downs: Additional Controls for Accounting Treatment}

This table presents a multivariate analysis of the factors related to the timeliness of write-downs, including additional control variables. Panel $\mathrm{C}$ includes additional controls for exposure-specificity, monoline hedges, and the accounting treatment. Standard errors (in brackets) are clustered at the firm level and at the quarter level. ***,** and $*$ denote significance at the $1 \%, 5 \%$ and $10 \%$ levels, respectively, using two-tailed tests. The additional control variables are defined in Chapter 5.4. Other variables are defined in Table 1, Panel B.

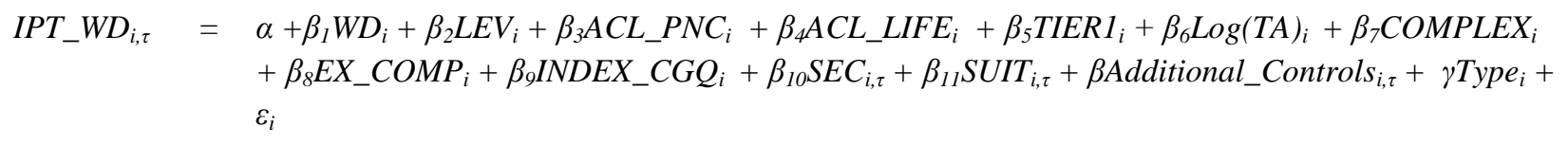

\begin{tabular}{|c|c|}
\hline & I. \\
\hline \multirow[t]{2}{*}{$W D$} & -0.017 \\
\hline & [0.118] \\
\hline \multirow[t]{2}{*}{$\log (T A)$} & 0.007 \\
\hline & [0.009] \\
\hline \multirow[t]{2}{*}{$L E V$} & $-0.383^{*}$ \\
\hline & [0.196] \\
\hline \multirow[t]{2}{*}{$A C L \_P N C$} & $0.001 * *$ \\
\hline & {$[0.000]$} \\
\hline \multirow[t]{2}{*}{$A C L \_L I F E$} & 0.001 \\
\hline & {$[0.001]$} \\
\hline \multirow[t]{2}{*}{ TIER1 } & 0.028 \\
\hline & {$[0.024]$} \\
\hline \multirow[t]{2}{*}{ COMPLEX } & $-0.118^{*}$ \\
\hline & {$[0.063]$} \\
\hline \multirow[t]{2}{*}{ EX_COMP } & -0.055 \\
\hline & {$[0.220]$} \\
\hline \multirow[t]{2}{*}{$I N D E X_{-} C G Q$} & $0.001 * *$ \\
\hline & {$[0.000]$} \\
\hline \multirow[t]{2}{*}{$S E C$} & 0.101 \\
\hline & [0.101] \\
\hline \multirow[t]{2}{*}{ SUIT } & $0.036^{*}$ \\
\hline & [0.019] \\
\hline \multirow[t]{2}{*}{ LESS_RISKY } & $-0.042 * * *$ \\
\hline & [0.013] \\
\hline \multirow[t]{2}{*}{ MONOLINE } & $-0.505^{* *}$ \\
\hline & {$[0.240]$} \\
\hline \multirow[t]{2}{*}{ IMPAIRMENT } & 0.013 \\
\hline & {$[0.061]$} \\
\hline \multirow[t]{2}{*}{ REALIZED } & 0.409 \\
\hline & [0.339] \\
\hline PROVISION & $-0.114^{* *}$ \\
\hline
\end{tabular}


